\title{
BULANIK KARAR VERME YAKLAŞIMIYLA KATILIM BANKALARI FINANSAL PERFORMANSI
}

\author{
Aykut KARAKAYA ${ }^{1}$
}

\begin{abstract}
Öz
İslami bankaları geleneksel bankalarla kıyaslandığında daha hızlı büyümektedir. Bunun nedeni, faizsiz finans ilkeleridir. Benzer durum Türkiye'deki katııım bankaları içinde geçerlidir. Finansal sistem içindeki artan ağırlığı katıım bankalarının performanslarını önemli kılmaktadır. Bu çalışmayla, Türkiye'deki katılım bankalarının CAMELS sistemine göre performans ölçümü amaçlanmıştır. Çalışmanın veri seti; Albaraka Türk, Kuveyt Türk, Türkiye Finans Katılım, Vakıf Katılım ve Ziraat Katılım Bankası'nın finansal oranlarını kapsamaktadır. Finansal oranlar 2018 yılı yıllık verileridir. Çalışmada öncelikle, CAMELS bileşenlerini oluşturan finansal oranların ağırıkları BAHS (Bulanık Analitik Hiyerarşi Süreci) ile hesaplanmıştır. Ardından. TOPSıS'le katılım bankaları finansal performans açısından sıralanmıştır. CAMELS sermaye, aktif kalitesi, yönetim kalitesi, kazanç, likidite ve piyasa risk duyarlıığı olmak üzere altı bileşenden oluşmaktadır. Çalışmada CAMELS çerçevesinde toplam 18 finansal oran kullanılmıştır. BAHS analizinde, CAMELS bileşenleri ana kriter ve finansal oranlar kriterdir. BAHS analizinde ana kriterlerin ağırlıklarına göre sırasının kazanç, sermaye, aktif kalitesi, likidite, yönetim kalitesi ve riske duyarlılık biçiminde bulunmuştur. Ağırlı̆̆ en yüksek kriterler ise, öz kaynak karlııı̆ı, risk ayarlı öz kaynak oranı, takipteki krediler oranı, öz kaynak oranı, aktif karlılık oranı ve cari orandır. TOPSıS analizi sonucunda ise, Türkiye'deki katılım bankalarının finansal performans sıralaması; Kuveyt Türk, Ziraat Katılım, Vakıf Katılım, Türkiye Finans Katılım ve Albaraka Türk şeklinde hesaplanmıştır.
\end{abstract}

Anahtar Kelimeler: Katılım Bankaları, Performans Analizi, CAMELS, BAHS, TOPSIS

JEL SInıflandırması: G21, L25, G28, C61

\section{FINANCIAL PERFORMANCE OF PARTICIPATION BANKS WITH FUZZY DECISION MAKING APPROACH}

\begin{abstract}
Islamic banks are growing faster than conventional banks. This is due to the principles of interest-free finance. The same is true of participation banks in Turkey. The increasing weight within the financial system makes the performance of participation banks important. This study aims to measure performance of participation banks in Turkey, according to the CAMELS system. Study data set covers financial ratios of Albaraka Turkish, Kuwait Turkish, Turkey Finans Participation, Vakif Participation, and Ziraat Participation Bank. Financial ratios are the annual data for 2018. First, the weights of the financial ratios that make up the CAMELS components are calculated by BAHS (Fuzzy Analytic Hierarchy Process). Then, TOPSIS and participation banks were ranked in terms of financial performance. CAMELS is consists of six components capital (C), asset quality (A), management quality (M), earnings (E), liquidity (L), and market risk sensitive (S). In this study, a total of 18 financial ratios were used within the framework of CAMELS. CAMELS are the components are the main criterion and financial ratios the criterion in BAHS analysis. In the BAHS analysis, the order of the main criteria according to their weights was found as earnings, capital, asset quality, liquidity, management quality and sensitivity. The highest weighted criteria are equity profitability ratio, risk adjusted equity ratio, nonperforming loans ratio, equity ratio, asset profitability ratio and current ratio. As a result of analysis of the financial performance TOPSIS ranking of participation banks in Turkey; Kuwait Turkish, Ziraat Participation, Vakif Participation, Turkey Finans Participation, and Albaraka Turk is calculated manner.
\end{abstract}

Keywords: Participation Banks, Performance Analysis, CAMELS, BAHP, TOPSIS

JEL Classification: G21, L25, G28, C61

${ }_{1}$ Dr. Öğretim Üyesi, Recep Tayyip Erdoğan Üniversitesi, iktisadi ve idari Bilimler Fakültesi, İşletme Bölümü, Rize, aykut.karakaya@erdogan.edu.tr, orcid.org/0000-0001-6491-132X 


\section{Giriş}

1970'li yılların başındaki petrol krizinin petrol ihraç eden İslam ülkeleri açısından İslami finans sistemine ihtiyaç doyulmasıyla İslami bankalar dünya finans sisteminde boy göstermeye başlamıştır. İslami bankalar 21. Yüzyılda küresel finansla da bütünleşerek geleneksel bankaların karşılayamadığı farklı istek ve ihtiyaçlara cevap verebilecek ürün, yöntem ve hizmet çeşitliliğine kavuşmuştur. 2008 yılındaki Küresel finansal krizin ortaya çıkışıyla, gelişmekte olan ülkelerin dünya ekonomisi içerisindeki yatırım fırsatları anlamındaki artan önemi ile birlikte faizsiz finans sisteminin gelişimi daha da hız kazanmıştır. Faizsiz finans uygulamalarının bankacılık alanında sunduğu gelişmeler geleneksel bankacılık faaliyetlerine tamamlayıcı nitelik taşıdığından, küresel finans sistemi açısından yenilikler ve fırsatlar sunmaktadır. İlk dönemlerinde gelişmekte olan ülkelerde faaliyetlerin yoğunlaştığı faizsiz finans sistemi, uluslararası bankaların faizsiz bankacılık faaliyetlerine dâhil olmalarının ardından birçok gelişmiş ülkede faaliyet yürütmeye başlamışlardır.

Türkiye'de katılım bankaları ilk olarak 1983 yılında "Özel Finans Kurumları" adıyla kurulmuş olup, 5411 sayılı Bankacılık Kanunu ile özel finans kurumları 2006 yılında "katılım bankası" adını almıştır (Bulut ve Er, 2012; 25). Dolayısıyla, kâr ve zarara katılma esasına dayalı olarak çalışan ve risk paylaşımını öngören İslami bankacılık sistemi, dünyada daha çok İslami bankacılık ya da faizsiz bankacılık olarak bilinmesine rağmen Türkiye'de "Katılım Bankacılı̆̆ı" kavramı ile tanımlanmaktadır (Parlakkaya ve Çürük, 2011: 397).

Küresel finansal krizin Türkiye' deki geleneksel bankacılık üzerindeki olumsuz etkiler yaratmış ve Türkiye'deki katılım bankacılığının bankacılık sistemi içerisindeki ağırlığı düzenli biçimde artış göstermiştir. Türkiye Katılım Bankaları Birliği'nin 2018 yılı faaliyet raporuna göre, geleneksel bankaların küresel krizle birlikte faaliyetlerinde aksamalar olmasına rağmen, katılım bankaları bundan daha az etkilenmişlerdir. Aynı raporda, 2018 yılı itibariyle, katılım bankalarının aktifleri, öz kaynakları, şube ve personel sayısı krizden sonra ortalama olarak iki haneli seviyede büyüme kaydetmiştir. Ayrıca, 2017 yılına göre 2018 yılı büyüme oranları aktifte ve kredilerde \%19, mevduatta \%15 ve kârda \%10 seviyesinde gerçekleşmiştir. Benzer biçimde, şube sayısı büyüme oranı $\% 9$, personel sayısındaki büyüme oranı ise $\% 4,2$ 'dir. Bankacılık sistemindeki toplam 50 bankadan, 45'i geleneksel banka ve 5'i katılım bankasıdır. Ilaveten, bankacılık sistemi aktifi içerisindeki katılım bankalarının payı yaklaşık \%5,4'e ulaşmıştır. Aktif büyüklükleri açısından katılım bankaları Kuveyt Türk, Türkiye Finans, Albaraka Türk, Ziraat Katılım ve Vakıf Katılım olarak sıralanmıştır. Net kar açısından sıralama ise, Kuveyt Türk, Türkiye Finans, Vakıf Katılım, Ziraat Katılım ve Albaraka Türk biçimindedir. Net karını en hızıı artıranlar Vakıf Katılım, Ziraat Katılım ve Kuveyt Türk olmuştur. Bir bütün olarak bakıldığında 2018 yılında faiz riski taşımayan katılım bankaları geleneksel bankaların tersine açık pozisyon dolayısıyla kur riski de yüklenmemişlerdir (TKBB, 2019: 41-49). İstikrarlı biçimde bankacılık sektör ortalamalarının üzerinde büyüyen katılım bankalarının Türkiye finans sistemi içindeki ağırlığı artırmaktadır. Türkiye ekonomisinin sürdürülebilir büyümesine yaptıkları sürekli katkı bir bütün olarak değerlendirildiğinde, katılım bankacılığı sektörünün ülkemiz finans sisteminin temel taşlarından biri konumuna geldiği ortaya çıkmaktadır.

Türkiye ekonomisi ve bankacılık sistemi içerisinde önemli rol oynayan katılım bankalarının finansal performansının değerlendirilmesi, performans üzerinde kritik faktörlerin ortaya konması ve performans açısından sıralaması bu çalışmanın amacını oluşturmaktadır. Bu amacı gerçekleştirmek için, çalışma da katılım bankalarının finansal performansı Bulanık Çok Kriterli Karar Verme Yöntemleri (ÇKKVY)'inden Bulanık Analitik Hiyerarşi Süreci (BAHS) ve TOPSIS (Technique for Order Preference by Similarity to Ideal Solution-İdeal Çözümle Benzerlik Yoluyla Sıralama Tekniği) kullanılarak ölçülmüştür. Performans analizinde kullanılan kriterler, bankacılık otoriterlerinin bankaların uzaktan gözetim ve denetiminde en sık başvurdukları kontrol ve gözetim sistemlerinden birisi olan CAMELS sisteminin finansal oranlarıdır. Çalışmada hali hazırda bağımsız biçimde faaliyette bulunan Albaraka Türk, Kuveyt Türk, Türkiye Finans Katılım, Vakıf Katılım ve Ziraat Katılım Bankası'nın 2018 yılı finansal performansları hesaplanmış ve katılım bankaları finansal 
performanslarına göre sıralanmıştır. Böylece, Türkiye'deki katılım bankalarının finansal performansında finansal oranların hangi düzeyde önemli olduğu bulanık karar verme yaklaşımıyla tespit edilmiş ve hangi katılım bankalarının finansal performansının daha iyi olduğu ortaya konmuştur.

Çalışma altı bölümden oluşmuştur. İkinci bölümde CAMELS sistemi kavramsal ve uygulama açısından ele alınmıştır. Araştırma yönteminin sunulduğu üçüncü bölümde BAHS ve TOPSIS analizleri hakkında bilgiler verilmiştir. Dördüncü bölümde araştırma veri seti ve değişkenleri tanıtılmıştır. Beşinci bölümde araştırma bulguları sunulmuştur. Altıncı bölümde ise, araştırmadan elde edilen sonuçlar aktarılmış ve değerlendirmeler yapılmıştır.

\section{CAMELS Sistemi}

Bankacılık denetim ve gözetim sistemleri ülkelerde farklılık arz etmekle birlikte, uygulamada iki temel sistemden söz etmek mümkündür. Bunlardan ilki yerinde denetim ikincisi ise, uzaktan gözetim sistemleridir.

Yerinde denetim sitemleri, denetçilerin bizzat bankalara giderek bankaları ayrıntılı olarak denetime tabi tutarak değerlendirmeleriyle gerçekleştirilir. Yerinde denetimde, bankanın finansal performansı, kredilerinin sınıflandırılması, donuk kredilerin yapısı, batık krediler, sermaye yeterliliği, yöneticilerin yetenek ve uzmanlıkları hakkında veriler toplanmaktadır. Yerinden denetimlerde değerlendirmelerde, denetçinin kişisel görüşleri de yer almaktadır. Yerinde denetimler bankaların finansal başarısızlıklarının tahmininde önemli bir yer tutmaktadır (Curry vd., 2003: 2-3). Yerinde denetim, bankaların performanslarının daha ayrıntılı değerlendirilmesine imkân vermesine rağmen, denetim sıklığı bankalarda ilave maliyetlere neden olmasının yanı sıra yoğun emek gerektirmektedir (Gilbert vd., 2000: 5-6).

Denetim otoriterleri, bankaların finansal durumunun güncel olarak değerlendirilmesini sağlamak ve periyodik olarak yapılan yerinde denetimi desteklemek amacıyla uzaktan gözetim veya erken uyarı sistemlerine başvurmaktadır (Cole ve Gunther, 1998: 2). Uzaktan gözetim sistemleriyle, bankacılık sektörünün sürekli olarak kontrol altında tutulabilmesi ve bankaların finansal yapılarının sağlam olmasını garanti altına alınabilmesinin yanında ekonomiyi etkileyebilecek bankacılık kökenli olumsuzlukların önceden tahmin edilip önlem alınabilmesi amaçlanmaktadır. Bu sistemler genellikle bankalardan alınan finansal raporların, çeşitli yöntemlerle incelenmesi ve yorumlanmasına dayanmaktadır (Çinko ve Avcı, 2008: 26-27).

1979 yılında $A B D^{\prime}$ de bankacılık sektörünü düzenleme ve denetleme kuruluşu olan Federal Finansal Kurumlar İnceleme Konseyi (Federal Financial Institutions Examination Council-FFIEC) tarafından, CAMEL sistemini kurmuştur. CAMEL sistemi, ABD Para Denetleme Bürosu (Office of the Comptroller of Currency-OCC), ABD Merkez Bankası (FED) ve FDIC tarafından kullanılmıştır. CAMEL sistemi beş bileşenden oluşmaktadır. Bunlar; sermaye yeterliliği (C), aktif kalitesi (A), yönetim kalitesi (M), kazanç (E) ve likidite (L)'dir. 1996 yılında CAMEL, piyasa riskine duyarlılığı simgeleyen (S) altıncı bileşenin eklenmesi ile CAMELS halini almıştır (Cole ve Wu, 2009: 2). Başlangıçta sadece ABD'deki bankalarda uygulanan CAMELS takip eden dönemlerde birçok ülkenin bankacılık denetleme ve düzenleme kurumu tarafından kabul görmüş ve $A B D$ dışında da yaygın biçimde uygulanmıştır. Literatürde CAMELS'in söz konusu bileşenlerinin bankaların düzenlemelere uyumunu ve faaliyet gücünü yansıtabildiği yönünde genel bir görüş birliğinden söz edilebilir (Gilbert vd., 2000: 6). Dolayısıyla da, uzaktan gözetim için kullanılan sistemler arasında, literatürde en öne çıkan CAMELS sistemidir (King. vd., 2006: 60). Aşağıda kavramsal olarak açıklanan CAMELS sisteminin bileşenleri ayrıca Şekil 1'de gösterilmiştir. 
Şekil 1: CAMELS Sistemi Bileşenleri

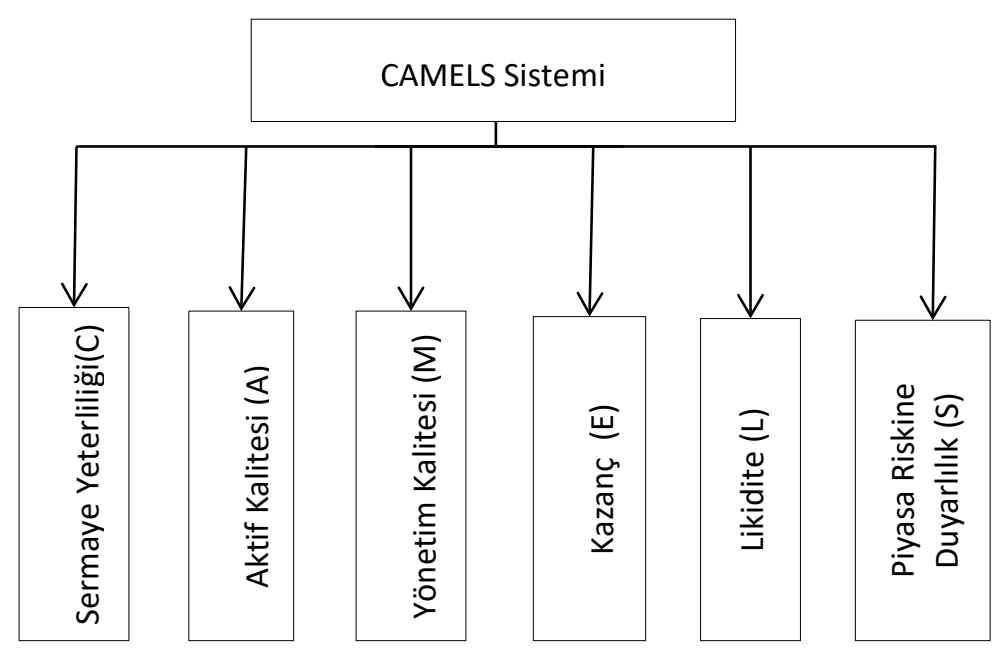

Sermaye Yeterliliği (C): Sermaye bileşeni, ödeme gücü riski ile doğrudan ilişkilidir. Bu riskin yönetimi bankanın uzun dönemli varlığını devam ettirebilmesi bakımından önemlidir. Ödeme gücü riski, bankanın karşılaştığı risklerden kaynaklanan kayıplarını, sermayesiyle karşılayabilme yeteneğinin olmaması biçiminde ifade edilebilir (Canbaş ve Doğukanlı, 2012: 159). Bu bileşen vasıtasıyla bankanın sermaye yeterliliği miktar ve kalite bakımından değerlendirilmektedir.

Aktif Kalitesi (A): Bilanço dışı işlemlerin yanı sıra, bilançodaki varlıkların kalitesini yani mevcut ve potansiyel kredi riskini göstermektedir. Yönetim tarafından kredi riskinin tanımlanması, ölçülmesi, takip edilmesi ve kontrolü bu bileşen içerisinde değerlendirilmektedir.

Yönetim Kalitesi (M): Bu bileşende, yönetim kurulu ve yönetimin, kendi görev ve sorumlulukları ile ilgili olarak, kurumun mevcut faaliyetleri ile ilgili riskleri belirlemesi, ölçmesi, takip ve kontrol etmesi ele alınmaktadır. Ayrıca, kurumun yürürlükteki yasa ve yönetmeliklere uygun olarak güvenli ve etkili iletişimini sağlama kabiliyeti de yönetim kalitesinin kapsamına girmektedir.

Kazanç (E): Bu bileşende elde edilen kazançların miktar, eğilim ve kalitesini etkileyen faktörler belirlenmektedir. Kazanç bileşeninde mevcut durumun devamı yanında kazançların tarihsel ve kalitesi açısında değerlendirilmesi üzerinde durulmaktadır. Burada bankanın verimli ve kârlı bir şekilde çalmasına ilaveten maliyetlerini düşük tutabilmesi de irdelenmektedir.

Likidite (L): Bankalar yükümlülüklerini karşılamanın yanında kredi talep edenlere kredi tahsis etme endişesi de taşırlar. Bu durum likidite riski olarak ifade edilmektedir (Korkmaz ve Ceylan, 2012: 33-34). Likidite riski banka karlılığını etkilemektedir. Bu bileşenle, fon taleplerini normal maliyetle karşılayabilme yeteneği olan likidite riski ortaya konmaktadır. Likidite riski, bankanın likidite açığı olduğunda varlıklarını kayba uğramadan nakde dönüştürebilmesi veya likidite açığını kapatacak normal düzeyde maliyetli fon bulabilmesi yeteneği ile ilgilidir. Böylece, bankaların kısa vadeli yükümlülükleri ve aniden ortaya çıkan nakit çıkışlarını karşılayabilme yeteneği ele alınmaktadır.

Piyasa Riskine Duyarılık (S): Piyasa riski finansal piyasalarda oluşan volatiliteye bağlı olarak faiz oranları, döviz kurları ve varlık fiyatlarında meydana gelen değişmeler sonucunda, bankanın zarar etme veya sermaye kaybetme riskini göstermektedir (Canbaş ve Doğukanlı, 2012: 157). Bu bileşen yoluyla, söz konusu değişimlerin bankaların kazançlarını veya sermayesini etkileme derecesi ortaya konmaktadır. Piyasa riskinin kontrolü için özellikle faiz oranı riskinin ve kur riskinin tanımlanması ve yönetilmesi gerekmektedir. Gözetim ve denetim otoriteleri, banka performansı üzerinde doğrudan önemli etkisi bulunduğundan piyasa riskinin ölçüm ve yönetimini belirli kurallara bağlanmaya çalışmaktadırlar. 


\section{CAMELS Literatürü}

Literatürde CAMELS sistemi sadece bankaların performansının ölçümüyle sınırlı olmayan biçimde daha geniş kullanım alanı bulmuştur. Bu alanlardan birisi olarak, bankaların finansal sıkıntı veya iflasın tespitinde CAMELS sistemi finansal oranlarının kullanılması sayılabilir. Cole ve Gunther (1995), DeYoung (1998), Gilbert vd. (2000), Çinko ve Avcı (2008), Kumar ve Ravi (2007), Poghosyan ve Cihák (2009), Männasoo ve Mayes (2009), Zhao vd. (2009), Christopoulos vd. (2011), Avkiran ve Cai (2012), Betz vd. (2014), Wanke vd. (2015) ve Wanke vd. (2016) ve Vousinas (2018) tarafından yapılan araştırmalar bu konudaki çalışmalara örnek gösterilebilir. Söz konusu çalışmalarda, CAMELS sistemi finansal oranları yardımıyla bankaların finansal sıkıntı veya iflas olasılığının başarılı biçimde tespit edilebildiği gösterilmiştir.

CAMELS sisteminden yararlanılan alanlardan bir diğeri bankaların kredi değerlendirmesidir. Bankaların kredi değerlenmesinde CAMELS sistemi finansal oranlarının kullanıldığı çalışmalara Barr vd. (1994), Dincer vd. (2015), Bao (2018) ile Shaddady ve Moore (2018) tarafından yapılan araştırmalar örnek olarak verilebilir. Çalışmalar sonucunda, CAMELS sistemi finansal oranlarının bankaların kredi değerlendirmesinde etkili biçimde kullanabileceği elde edilmiştir.

CAMELS sisteminin diğer bir kullanım alanı olan da bankaların rekabet edebilirliği konusudur. Bankaların rekabet gücünün analiz edildiği Xie (2013), Bastan vd. (2016) ve Tao (2017) tarafından yapılan çalışmalarda, CAMELS sistemi başarıyla uygulanmıştır. Bulgulardan yola çıkılarak, CAMELS sistemi finansal oranlarının bankaların rekabet edebilirliğinin ölçülmesinde kullanışlı olduğu ortaya konmuştur.

CAMELS sisteminin en geniş kullanım alanı olan konu, bankaların performans değerlendirmesidir. Banka performans değerlemesi amacıyla CAMELS sisteminde yer alan finansal oranların kullanıldığı çalışmalar hakkındaki özet bilgiler yukarıda Tablo 1'de sunulmuştur.

Tablo 1'de sunulan çalışmalara bakıldığında altı grup altında toplanabilir. İlki geleneksel olan CAMELS bileşenleri ve finansal oranların eşit ağırlığa sahip olduğunu varsayan 1-5 arası puanlamayla CAMELS bileşenlerinden tek bir CAMELS endeksinin elde edildiği çalışmalardır. Bu tür çalışmalar sadece erken dönemlerde değil son dönem çalışmalar içerisinde de ağırlık teşkil etmektedir. Ersoy (2003), Nurazi ve Evans (2005), Sarker (2005), Solak (2010), Jaffar ve Manarvi (2011), Merchant (2012), Gündoğdu (2017), Bayramoğlu ve Gürsoy (2017), Altemur vd. (2018), Erdoğan ve Karaca (2018) ile Uslu (2019) tarafından yapılan çalışmalar bu tür çalışmalara örnek verilebilir.

İkinci gruptakiler, CAMELS bileşenleri ve finansal oranların farklı ağırlığa sahip olduğu yine 1-5 arası puanlamayla CAMELS bileşenlerinden tek bir CAMELS endeksinin elde edildiği çalışmalardır. Kaya (2001), Kılıç ve Fettahoğlu (2005) ile Emir ve Çizgici Akyüz (2018)'ün çalışmaları bu grupta yer alan çalışmalardandır.

Üçüncü gruptakiler istatistik ve ekonometri analiziyle CAMEL bileşenleri veya CAMEL bileşik endeksi bağımsız değişken olarak ele alınmakta banka performansı üzerindeki etkisi ortaya koymaktadır. Bu grupta Whalen ve Thomson (1988), Kaya (2001), Ramirez vd. (2005), Günsel (2007), Rozzani ve Rahman (2013) ile Muhmad ve Hashim (2015)'in çalışmaları yer almaktadır.

Dördüncü grup çalışmalar, matematiksel yöntemler olan ÇKKVY ile CAMELS bileşenlerini değil, bileşenler altında toplanan finansal oranlara göre banka performansını değerlendirmektedir. Bu çalışmalarda finansal oranlara eşit ağırlık verilmiştir. Dolayısıyla, banka performansı açısından oranların tümü aynı önemde kabul edilmiştir. Gündoğdu (2018)'nun çalışması bu grup içerisindedir. 
Tablo 1: Banka Performans Değerlemesinde CAMELS Sisteminin Kullanıldığı Çalışmalar

\begin{tabular}{|c|c|c|c|}
\hline Yazar ve Yıl & Uygulama Yeri & Yöntem & Değişkenler \\
\hline Whalen ve Thomson (1988) & $A B D$ & Lojistik Regresyon Analizi & CAMELS Endeksi \\
\hline Kaya (2001) & Türkiye & Probit Regresyon Analizi & CAMELS Endeksi \\
\hline Ersoy (2003) & Türkiye & Karşılaştırmalı Analiz & CAMELS Endeksi \\
\hline Ramirez vd. (2005) & $A B D$ & Regresyon Analizi & CAMELS Endeksi \\
\hline Kılıç ve Fettahoğlu (2005) & Türkiye & Karşılaştırmalı Analiz & CAMELS Endeksi \\
\hline Nurazi ve Evans (2005) & Endonezya & Karşılaştırmalı Analiz & CAMELS Oranları \\
\hline Sarker (2005) & Endonezya & Karşılaştırmalı Analiz & CAMELS Endeksi \\
\hline Günsel (2007) & KKTC & Lojistik Regresyon Analizi & CAMELS Endeksi \\
\hline Seçme vd. (2009) & Türkiye & AHS ve TOPSIS & CAMALS Oranları \\
\hline Solak (2010) & Türkiye & Karşılaştırmalı Analiz & CAMELS Endeksi \\
\hline Jaffar ve Manarvi (2011) & Pakistan & Karşılaştırmalı Analiz & CAMELS Endeksi \\
\hline Merchant (2012) & Körfez Ülkeleri & Karşılaştırmalı Analiz & CAMELS Endeksi \\
\hline Aytekin ve Sakarya (2013) & Türkiye & Karşılaştırmalı Analiz & CAMELS Endeksi \\
\hline Kandemir ve Arıcı (2013) & Türkiye & Karşılaştırmalı Analiz & CAMELS Endeksi \\
\hline Rozzani ve Rahman (2013) & Malezya & Panel Veri Analizi & CAMELS Endeksi \\
\hline Roman ve Şargu (2013) & Romanya & Karşılaştırmalı Analiz & CAMELS Endeksi \\
\hline Abdullayev (2013) & Türkiye & Karşılaştırmalı Analiz & CAMELS Oranları \\
\hline Aslan (2014) & Türkiye & Karşılaştırmalı Analiz & CAMELS Endeksi \\
\hline Helhel ve Varshalomidze (2014) & Gürcistan & Karşılaştırmalı Analiz & CAMELS Endeksi \\
\hline Çağıl ve Mukhtarov (2014) & Azerbaycan & Karşılaştırmalı Analiz & CAMELS Endeksi \\
\hline Muhmad ve Hashim (2015) & Malezya & Regresyon Analizi & CAMELS Endeksi \\
\hline Islam ve Ashrafuzzaman (2015) & Bangladeş & Karşılaştırmalı Analiz & CAMELS Endeksi \\
\hline Ege vd. (2015) & Türkiye & Karşılaştırmalı Analiz & CAMELS Endeksi \\
\hline Gümüş ve Nalbantoğlu (2015) & Türkiye & Karşılaştırmalı Analiz & CAMELS Endeksi \\
\hline Güney ve Ilgın (2015) & Türkiye & Karşılaştırmalı Analiz & CAMELS Endeksi \\
\hline Wanke vd. (2016) & G. Doğu Asya & BAHS, TOPSIS ve YSA & CAMELS Oranları \\
\hline Gündoğdu (2017) & Türkiye & Karşılaştırmalı Analiz & CAMELS Oranları \\
\hline Gündoğdu (2018) & Türkiye & Gri İlişki Analizi & CAMELS Oranları \\
\hline Karakaya (2017) & Türkiye & AHS ve TOPSIS & CAMELS Oranları \\
\hline Bayramoğlu ve Gürsoy (2017) & Türkiye & Karşılaştırmalı Analiz & CAMELS Oranları \\
\hline Altemur vd. (2018) & Türkiye & Karşılaştırmalı Analiz & CAMELS Endeksi \\
\hline Emir ve Çizgici Akyüz (2018) & Türkiye & Karşılaştırmalı Analiz & CAMELS Endeksi \\
\hline Erdoğan ve Karaca (2018) & Türkiye & Karşılaştırmalı Analiz & CAMELS Endeksi \\
\hline Uslu (2019) & Türkiye & Karşılaştırmalı Analiz & CAMELS Endeksi \\
\hline
\end{tabular}

Beşinci grupta ÇKKVY ile CAMELS bileşenlerini de dikkate alan, bileşenlere ve finansal oranlara banka performansına katkısı açısından uzmanların görüşleri dâhilinde farklı ağırlık veren çalışmalar yer almaktadır. Seçme vd. (2009) ile Karakaya (2017) tarafından yapılan çalışmalar bu gruptadır.

Son grupta ise, bulanık ÇKKVY ile CAMELS bileşenleri ve finansal oranlarına performansa katkısı dâhilinde uzman görüşleri yoluyla farklı ağılıkların verilmiştir. Wanke vd. (2016) tarafından yapılan çalışma bu gruba örnek verilebilir.

CAMELS sistemi finansal oranlarıyla Türkiye'deki katılım bankalarının performans değerlendirmesi üzerine bulanık ÇKKVY'nin kullanıldığı çalışmaya rastlanmamıştır. Bu yönüyle var olan bir boşluğu doldurması beklenen bu çalışmanın ilk olma özelliği taşıdığı düşünülmektedir.

\section{Araştırma Yöntemi}

Örneklem büyük ve değişkenler belirli bir dağılım özelliği gösteriyorsa finansal performansın belirlenmesinde istatistiksel ve ekonometrik analiz yöntemlerinden faydalanılabilmektedir. Buna karşın, örneklem küçük ve dağılımı bilinmiyorsa finansal performansın ölçümünde istatistiksel ve 
ekonometrik yöntemlerin uygulanmasında güçlüklerle karşılaşılabilmektedir. Söz konusu bu kısıtları içermeyen Çok Kriterli Karar Verme Yöntemleri (ÇKKVY) finansal performansın hesaplamasında kolay biçimde uygulanabilmektedir.

Literatüre bakıldığında ÇKKVY'lerinin bankaları konu alan çalışmalarda tek bir yöntemle, bütünleşik, bulanık olmayan veya bulanık olan farklı biçimlerde uygulandığı gözlenmiştir. Tek başına ÇKKVY uygulayan çalışmalara VIKOR Ertuğrul ve Karakaşoğlu (2008), TOPSIS Çakır ve Perçin (2013), Eyüpoğlu (2016) ve Dursun ve Bozkır (2018), Gri illişkisel Analiz Gündoğdu (2018) tarafından yapılan çalışmalar örnek verilebilir. AAS ve TOPSIS Tsai vd., (2008), AHS ve TOPSIS Perçin (2009) ve Karakaya (2017), AHS ve GIA Wu vd. (2010), AHS, TOPSIS ve VIKOR Dinçer ve Görener (2011), AHS ve COPRAS-G Ecer (2014), Entropi ve TOPSIS İslamoğlu vd. (2015) tarafından yapılan çalışmalar bütünleşik çalışmalardır. BAHS, SAW, TOPSIS, VIKOR Wu vd., (2009), BAHS ve TOPSIS Yalçın Seçme vd., (2009), BAHS ve Bulanık ELECTRE Kaya ve Kahraman (2011) uygulamaları da bulanık karar verme çalışmaları olarak dikkat çekmektedir.

Bu çalışmada katılım bankaları ile ilgili verilerin analizinde matematiksel olarak hem nitel hem de nicel kriterleri dikkate almaya imkân sağlayan bulanık ÇKKVY kullanılmıştır. Çalışmada BAHS ile finansal performans kriterleri olan CAMELS finansal oranların ağırlıkları belirlenmiştir. Ardından, TOPSIS ile de, katılım bankaları finansal performanslarına göre sıralanmıştır. Bulanık küme ve bulanık sayılar hakkında sunulan kısa bilginin ardından, aşağıdaki başlıklarda BAHS ve TOPSIS hakkında kavramsal ve uygulama adımları ile ilgili açıklanmalar verilmiştir.

L. Zadeh tarafından 1965 yılında literatüre kazandırılan Bulanık Küme Teorisi, insan kararlarındaki belirsizliğin sayısallaştırılmasına olanak sağlamaktadır. Klasik küme teorisindeki kesin sınırları olan küme kavramına karşın bulanık kümelerde, kısmi üyelik kavramı söz konusudur. Klasik küme teorisinde bir eleman o kümeye ya aittir ya da değildir yani ya 1'dir ya da 0'dır. Buna karşın bulanık kümelerde ise, ait olmanın bir derecesi söz konusudur. Bu dereceye üyelik derecesi denir. Üyelik derecesi klasik kümlerdeki 0 veya 1 gibi değildir, 0 ve 1 aralığında süreklilik gösterir (Kahraman vd.. 2004: 174, Perçin ve Karakaya, 2012: 246-247). Üyelik derecesi 1'e yaklaştıkça bir elemanın kümeye üyeliği artarken, üyelik derecesinin 0 'a yaklaşması bir elemanın kümeye üyeliğinin azalmaktadır. Bulanık sayılar bulanık kümelerin bir alt kümesidirler. Bulanık sayılar, Kesin olmayan ve tam tanımlanamayan nicelikleri temsil eden bulanık sayıların, literatürde en sık yaygın kullanılan türleri, üçgen bulanık sayılar ve yamuk bulanık sayılardır. Bu çalışmada, hesaplama ve gösteriminin daha kolay olmasından ötürü üçgen bulanık sayılar tercih edilmiştir. Üçgen bulanık sayıların gösterim biçimi $\tilde{A}=(I, m, u)$ şeklindedir. Burada, $I \leq m \leq u$ koşulu geçerlidir. $I$, olası en küçük değeri; $m$, en olası değeri ve $u$, olası en büyük değeri ifade eder (Kahraman vd.. 2004: 175).

\subsection{Bulanık Analitik Hiyerarşi Süreci (BAHS)}

ÇKKVY'den en yaygın olarak kullanılanı AHS'dir. AHS, ilk olarak 1971 yılında. Thomas L. Saaty tarafından çok kriterli karmaşık problemlerin çözümü için geliştirilmiştir (Eleren, 2007: 51). AHS farklı özellikteki kriterleri hiyerarşik bir yapıda bütünleştiren ve kriterler karsısındaki performansı tek bir değer olarak birleştiren matematiksel bir yöntemdir (İç ve Yurdakul, 2000: 5). AHS, her bir kriterin diğerlerine göre önem derecelerini belirlemek için karar vericilere intiyaç duyar. Karar vericilerin kriterlere verdikleri önem derecelerine göre alternatifler arasında bir tercih yapılır. Sonunda alternatifler önem sırasına konur (Anderson vd., 1997: 715). AHS, karar verme sürecinde önemli olan hem nitel hem de nicel kriterleri karşılaştırabilme özelliğine sahiptir. Literatüre bakıldığında araştırmacılar tarafından AHS yönteminin bulanıklaştırılması amacıyla geliştirilmiş farklı hesaplama yöntemleri ile ilgili birçok çalışmaya rastlanmak mümkündür. Bu çalışmada, Chang (1996) tarafından geliştirilen Mertebe (Derece) Analizi Metodu kullanılmasına karar verilmiştir. Bu yöntem, hesaplamasının görece basit olması, sunması ve etkin sonuçlar elde edilebilmesi bakımından yaygın biçimde kullanılmaktadır. Yöntem çok kriterli problemlerde kriterlerin ağırlıklarının yanında alternatiflerin sıralanarak aralarından en iyisinin seçilmesini imkân sağlaması nedeniyle literatürde farklı araştırmacılar tarafından tercih edilmektedir (Büyüközkan ve Ruan, 2007: 328). BAHS uygulanırken, ilk adım ana kriterlerin, kriterlerin, hedeflerin ve alternatiflerin 
dâhil olduğu karar hiyerarşisinin yapısı tanımlamaktır. Böylece araştırma modeli kurulmuş olur. Ardından kullanılan analiz yönteminin işlem adımları sırasıyla uygulanır. Bu çalışmada tercih edilen Chang'ın önerdiği BAHS yönteminin uygulama adımları aşağıda izah edilmiştir:

$Z=\left\{z_{1} \cdot z_{2} \cdot z_{3}, \ldots z_{n}\right\} \quad$ kriterlerin ve $U=\left\{u_{1} \cdot u_{2} \cdot u_{3} \ldots u_{n}\right\}$ amaçların kümesi olduğu varsayımından hareketle, her bir kriter ve amaç $\left(g_{i}\right)$ için hesaplama adımları uygulanır. Her bir kriterin amacı ne derece gerçekleştirdiğini ifade etmek için mertebe kavramı kullanılır. Böylece her bir kriter için $m$ adet mertebe analizi değeri $M_{g i}^{1} . M_{g i}^{2} \ldots . M_{g i}^{m}, i=1,2,3, \ldots, n$ elde edilir. Buradaki $M_{g i}^{j}(j=1,2,3, \ldots, m)$ değerleri bulanık üçgen sayılardır. Bu yöntem 4 aşamada uygulanır (Chang, 1996: 176-177):

1. Adım: Burada, i. kritere göre bulanık sentetik derece değerinin elde edilmesidir.

$$
S_{i}=\sum_{j=1}^{m} M_{g_{i}}^{i} \otimes\left[\sum_{i=1}^{m} \sum_{j=1}^{m} M_{g_{i}}^{j}\right]^{-1}
$$

$\mathrm{S}_{\mathrm{i}}=\mathrm{i}$. kriterin sentez değeri ve $M_{g i}^{j}=$ Her bir kritere yönelik genişletilmiş değerdir. $\sum_{j=1}^{m} M_{g_{i}}^{i}$ 'in elde etmek için, $m$ adet genişletilmiş derece analizi değerine aşağıda (3)-(4) nolu denklemlerde verilen matrisler yardımıyla bulanık toplama işlemi uygulanmaktadır. Öncelikle bulanık olmayan bilgiler Chen vd., (2006) tarafından önerilen aşağıdaki (2) nolu denklemde gösterilen biçimde üçgen bulanık sayılara dönüştürülür:

$\left(\tilde{M}_{i j}\right)=\left(l_{i j}, m_{i j}, u_{i j}\right) \quad l_{i j}=\min _{k}\left\{a_{i j k}\right\} \quad m_{i j}=\frac{1}{K} \sum_{k=1}^{K} b_{i j k} \quad u_{i j}=\max _{k}\left\{c_{i j k}\right\}$

$\mathrm{K}=$ Karar verici sayısı ve $\widetilde{\mathrm{M}}_{\mathrm{ij}}=$ Bulanık üçgen sayıdır.

$\sum_{j=1}^{m} M_{g_{i}}^{i}=\left(\sum_{j=1}^{m} l_{j}, \sum_{j=1}^{m} m_{j}, \sum_{j=1}^{m} u_{j}\right)$

$\left[\sum_{i=1}^{m} \sum_{j=1}^{m} M_{g_{i}}^{j}\right]^{-1}$ terimini hesaplamak üzere $M_{g_{i}}^{\mathrm{j}}(j=1,2, . ., m)$ değerleri için gerçekleştirilen bulanık toplama işlemi ise (4) nolu denklemdeki gibidir:

$$
\sum_{i=1}^{n} \sum_{j=1}^{m} M_{g_{i}}^{i}=\left(\sum_{i=1}^{n} l_{i}, \sum_{i=1}^{n} m_{i}, \sum_{i=1}^{n} u_{i}\right)
$$

Daha sonra elde edilen vektörün tersi aşağıdaki (5) nolu denklem ile hesaplanmaktadır:

$$
\left[\sum_{i=1}^{m} \sum_{j=1}^{m} M_{g_{i}}^{j}\right]^{-1}=\left(\frac{1}{\sum_{i=1}^{n} u_{i}}, \frac{1}{\sum_{i=1}^{n} m_{i}}, \frac{1}{\sum_{i=1}^{n} l_{i}}\right)
$$

2. Adım: $\widetilde{M}_{1}=\left(I_{1}, m_{1}, u_{1}\right)$ ve $\widetilde{M}_{2}=\left(I_{2}, m_{2}, u_{2}\right)$ iki bulanık sayıyı ifade etmek üzere $\widetilde{M}_{2} \geq \widetilde{M}_{1}$ durumunun yani $\widetilde{M}_{2}^{\prime}$ nin $\widetilde{M}_{1}^{\prime}$ e tercih edilme oranının (olasılık derecesinin) belirlenmesidir. İkinci adımda sentez değerlerinin karşılaştırılmasıyla ağırlık değerleri elde edilmektedir. $\widetilde{M}_{2} \geq \widetilde{M}_{1}$ eşitliğinin olabilirlik derecesi aşağıdaki (6) nolu denklemde gösterilmiştir:

$$
\mathrm{V}\left(\widetilde{M}_{2} \geq \widetilde{M}_{1}\right)=\sup _{y \geq x}\left[\min \left(\mu_{\widetilde{M}_{1}}(z), \mu_{\widetilde{M}_{2}}(y)\right)\right]
$$

$\mu_{\widetilde{M}_{1}}(z)=\mu_{\widetilde{M}_{2}}(y)$ ilişkisini sağlayan bir $(z, y)$ çifti söz konusu olduğunda olabilirlik derecesi $\mathrm{V}\left(\widetilde{M}_{2}\right.$ $\left.\geq \widetilde{M}_{1}\right)=1$ olarak elde edilmektedir $\widetilde{M}_{1}=\left(I_{1}, m_{1}, u_{1}\right)$ ve $\widetilde{M}_{2}=\left(I_{2}, m_{2}, u_{2}\right)$ konveks bulanık sayılar olduğu için $\mathrm{V}\left(\widetilde{M}_{2} \geq \widetilde{M}_{1}\right)$ değerleri aşağıdaki (7) nolu denklemde sunulmuştur: 


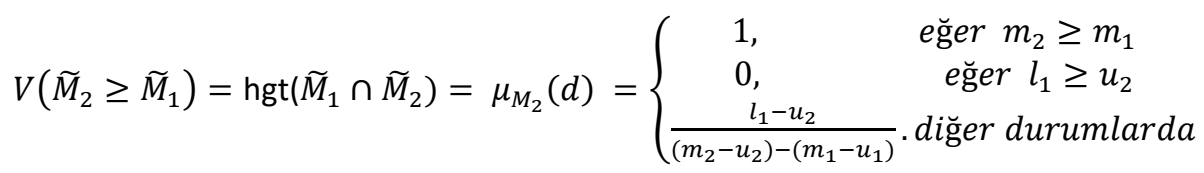

Burada $d$ ile $\mu_{M_{1}}$ ve $\mu_{M_{2}}$ arasındaki en yüksek kesişim noktasının ordinatıdır. Bu durum Şekil 1'de D ile gösterilmektedir. $\widetilde{M}_{1}$ ve $\widetilde{M}_{2}^{\prime}$ nin karşılaştırılabilmesi için $\mathrm{V}\left(M_{1} \geq M_{2}\right)$ ve $\mathrm{V}\left(M_{2} \geq M_{1}\right)$ değerlerinin her ikisine de ihtiyaç duyulmaktadır.

\section{Şekil 1: $\widetilde{\boldsymbol{M}}_{1}$ ve $\widetilde{\boldsymbol{M}}_{2}$ Sayılarının Kesişim Noktası}

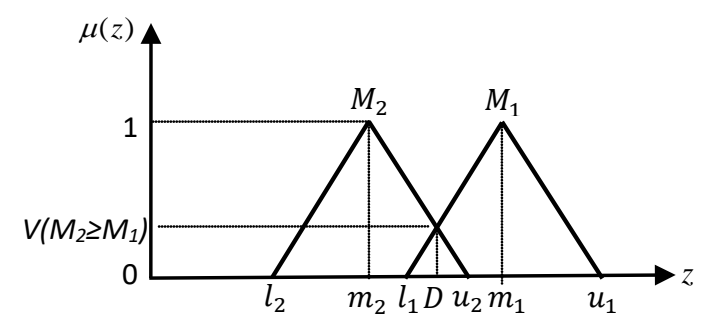

3. Adım: Konveks olan bir bulanık sayının $\mathrm{k}$ tane bulanık sayıdan. $\mathrm{M}_{\mathrm{i}}=(\mathrm{i}=1,2,3, ., \mathrm{k})^{\prime}$ den daha büyük olabilirlik derecesi aşă̆ıdaki şekilde elde edilmiştir.

$V\left(M \geq M_{1}, M_{2}, \ldots, k\right)=\min V\left(M \geq M_{i}\right), \quad i=1,2,3, \ldots, k$

Burada $S_{i .} k=1,2,3, \ldots n ; i \neq k$ için $d^{\prime}\left(A_{i}\right)=\min V\left(S_{i} \geq S_{k}\right) . k=1,2, .3, \ldots . n ; k \neq i$ varsayımı yapılmaktadır. Ağırlık vektörü; $A_{i}(i=1,2,3, \ldots . . . n)^{\prime}$ nin $n$ elemandan oluşan ağıllık vektörü aşağıdaki (9) nolu denklemde gösterilmiştir.

$W^{\prime}=\left(d^{\prime}\left(A_{1}\right) \cdot d^{\prime}\left(A_{2}\right) \ldots . d^{\prime}\left(A_{n}\right)\right)^{T}$

4. Adım: Normalleştirilmiş ağırlık vektörünün elde edilmesi. Normalleştirilmiş ağırlık vektörü, $W$ artık bulanık değil kesin bir sayıdır. Aşağıdaki (10) nolu denklemdeki biçimde hesaplanmıştır.

$d\left(A_{i}\right)=\frac{d^{\prime}\left(A_{i}\right)}{\sum_{i=1}^{n} d^{\prime}\left(A_{i}\right)} . \quad W=\left(d\left(A_{1}\right) \cdot d\left(A_{2}\right) \ldots . d\left(A_{n}\right)\right)^{T}$

Yukarıda anlatılan BAHS uygulama adımları bu çalışmada, katılım bankalarının CAMELS oranlarının öncelik değerlerinin (ağılıklarının) belirlenmesinde kullanıımışır. Aşağıda değinilen TOPSIS ile ağırlıkları belirlenen finansal oranlardan hareketle katılım bankalarının finansal performansları tespit edilmiştir.

\subsection{TOPSIS Yöntemi}

Bu çalışmada, katııım bankalarının CAMELS'e göre finansal performansının hesaplanmasında 1981 yılında Hwang ve Yoon tarafından ELECTRE yöntemine alternatif olarak geliştirilen TOPSIS (Technique for Order Preference by Similarity to Ideal Solution-İdeal Çözümle Benzerlik Yoluyla Sıralama Tekniği) kullanılmıştır. TOPSIS'in tercih edilmesinin nedeni. hesaplama basitliği ve hesaplanan değerlerin çok gerçekçi olmasıdır (Triantaphyllou vd., 1998: 181). TOPSIS değişkenlerin doğrusal biçimde değişim sergilediğini varsaymaktadır. TOPSIS'e göre en iyi alternatif; pozitif ideal çözüm noktasına en yakın ve negatif ideal çözüm noktasına en uzak olan sonucu veren alternatiftir (Benitez vd.. 2007). Burada pozitif ideal çözüm, fayda kriterlerinin maksimum ve maliyet kriterlerinin minimum değer aldığı noktayı göstermektedir. Buna karşın negatif ideal çözüm, fayda kriterlerinin minimum ve maliyet kriterlerinin maksimum olduğu noktayı vermektedir (Ertuğrul ve Karakaşoğlu, 2009). Aslında, pozitif ideal çözüm kriterler açısından ulaşılan en iyi değerken, negatif ideal çözüm ise tam tersi olan ulaşılan en kötü değeri içermektedir.

TOPSIS'in uygulama aşamaları aşağıda maddeler halinde verilmiştir (Agrawal vd., 1991: Triantaphyllou vd., 1998: Perçin ve Karakaya, 2012): 
Aşağıda satırlarda yer alan M alternatif sayısı ve sütunlarda yer alan N kriter sayısı olmak üzere D karar matrisi çerçevesinde TOPSIS'in uygulanması açıklanmaya çalışılacaktır. D karar matrisinin elemanı olan $X_{i j} j$. kriter açısından $i$. alternatifin performans ölçütünü göstermektedir.

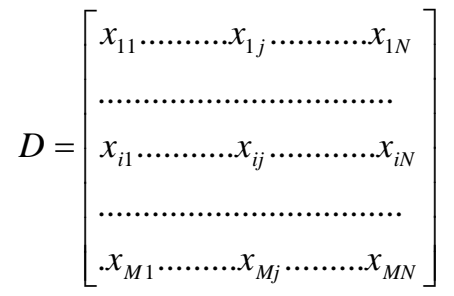

1. Kriterlerin Normal Değerlerinin Belirlenmesi: Burada karşılaştırılabilir bir ölçek oluşturulmaya çalışılmaktadır. D karar matrisi elemanlarının orijinal değerleri $x_{i j}$ ve orijinal değerlerin karelerinin toplamının karekökleri kullanılmak suretiyle vektör normal değeri hesaplanmaktadır. Böylelikle tek boyutlu karşılaştırılabilir bir vektör oluşturulmaktadır. Normal değerlerin hesaplanma formülü aşağıdaki (11) nolu denklemdedir:

$$
r_{i j}=\frac{x_{i j}}{\sqrt{\sum_{i=1}^{M} x_{i j}{ }^{2}}} \quad i=1,2,3, \ldots, M v e j=1,2,3, \ldots, N
$$

Burada, $i$ katılım bankaları, $j$ CAMELS finansal oranları ve $r_{i j} i$. katılım bankasının $j$. CAMELS finansal orana göre normal vektör değerini göstermektedir.

2. Kriterlerin Ağırıklı Normal Değerlerinin Belirlenmesi: Karar vericilerin kriterleri ikili karşılaştırması sonucu elde edilen, kriterlerin ağırlığı $w_{j}$ ile $r_{i j}$ değerinin çarpılması suretiyle elde edilir. Ağırlıklı normal değerin hesaplanma formülü (12) nolu denklemle gösterilebilir:

$$
v_{i j}=r_{i j} \times w_{j} \quad i=1,2,3, \ldots, M v e j=1,2,3, \ldots, N
$$

Burada. $w_{j} j$. CAMELS finansal oranının ağırlık değeri ve $v_{i j} i$ katılım bankasının $j$. CAMELS finansal oranına göre ağırıklı normal değerini göstermektedir. Ayrıca, $\sum w_{j}=1$ 'dir. Çalışmada, kriterler olan CAMELS finansal oranlarının ağırlıkları BAHS hesaplamaları sonucunda elde edilmektedir. Ağırlıklı normal matris V'nin genel gösterimi aşağıdaki gibidir:

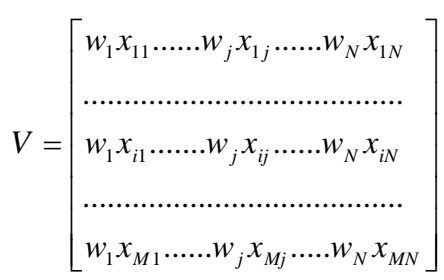

3. Pozitif ideal $\left(A^{*}\right)$ ve Negatif ideal $\left(A^{-}\right)$Çözümlerin Belirlenmesi: Fayda kriterinin maksimum değer alması, buna karşın maliyet kriterinin ise minimum değer alması arzu edilen durumdur. Böylece, her bir CAMELS finansal oranı için $A^{*}$ pozitif ideal çözümü yani en fazla tercih edilen katılım bankasını, $A^{-}$ise, negatif ideal çözümü veya en az tercih edilen katılım bankasını gösterecektir. Hesaplanma biçimi aşağıdaki (13) ve (14) nolu denklemlerde verilmiştir. 


$$
\begin{aligned}
& A_{j}^{*}=\left\{\left(\max _{i} v_{i j} \mid j \in J\right),\left(\min _{i} v_{i j}\left|j \in J^{\mid}\right| i=1,2,3, \ldots, M\right\}=\left\{v_{1}^{*}, v_{2}^{*}, v_{3}^{*}, \ldots, v_{N}^{*}\right\}\right. \\
& A_{j}^{-}=\left\{\left(\min _{i} v_{i j} \mid j \in J\right),\left(\max _{i} v_{i j}\left|j \in J^{\mid}\right| i=1,2,3, \ldots, M\right\}=\left\{v_{1}^{-}, v_{2}^{-}, v_{3}^{-}, \ldots, v_{N}^{-}\right\}\right.
\end{aligned}
$$

Burada. $J=1,2,3, \ldots, N$ fayda kriterlerini. $\quad J^{\mid}=1,2,3, \ldots, N$ maliyet kriterlerini temsil etmektedir.

4. Ayırma Ölçeğinin Hesaplanması: Öklid uzaklığı yöntemiyle her bir bankanın pozitif ideal çözüme $\left(A^{*}\right)$ ve negatif ideal çözüme $\left(A^{-}\right)$olan uzaklığı hesaplanır. Öklid uzaklığı formülü aşağıdaki (15) ve (16) nolu denklemlerle hesaplanmaktadır:

$$
\begin{gathered}
S_{i}^{*}=\left(\sum_{i=1}^{M}\left(v_{i j}-v_{j}^{*}\right)^{2}\right)^{1 / 2} i=1,2,3, \ldots, M \text { ve } j=1,2,3, \ldots, N \\
S_{i}^{-}=\left(\sum_{i=1}^{M}\left(v_{i j}-v_{j}^{-}\right)^{2}\right)^{1 / 2} i=1,2,3, \ldots, M \text { ve } j=1,2,3, \ldots, N
\end{gathered}
$$

Burada, $S_{i}^{*}$ pozitif ideal çözümden $\left(A^{*}\right)$ her bir katılım bankasının uzaklığı ve $S_{i}^{-}$negatif ideal çözümden $\left(A^{-}\right)$her bir katılım bankasının uzaklığını göstermektedir.

5. Ideal Çözüme Yakınlığın Hesaplanması: Her bir bankanın pozitif ideal çözüme olan yakınlı̆ını yakınık katsayısının hesaplanmasıyla bulunur. Yakınlık Katsayısı $\left(Y K_{i}\right) 1$ ile 0 arasında değer almaktadır. $Y K_{i}=1$ olan katılım bankası pozitif ideal katııım bankasını. $Y K_{i}=0$ olan katıım bankası ise negatif ideal katıım bankasını verecektir.

$$
Y K_{i}=\frac{S_{i}^{-}}{S_{i}^{-}+S_{i}^{*}}
$$

6. Alternatiflerin Sıralanması: Katılım bankaları $Y K_{i}$ en yüksek olandan en düşük olana doğru sıralanır. $Y K_{i}$ 'si en yüksek katııım bankası finansal performansı en iyi, $Y K_{i}$ 'si en düşük katııım bankası ise finansal performansı en kötü olan katılım bankasını göstermektedir. Dolayısıyla, YK değeri en büyük olan katılım bankası pozitif ideal çözüme en yakın ve negatif ideal çözüme en uzak katılım bankasını vereceğinden, finansal performansı en yüksek katııım bankasını gösterecektir.

\section{Veri ve Değişkenler}

Çalışma verileri Türkiye Katııım Bankaları Birliği (TKBB) internet sitesinde yayınlanan katıım bankalarına ait finansal bilgilerden oluşturulmuştur. Söz konusu bu finansal bilgiler, Tasarruf Sigorta Fonu'na devrolunan Bank Asya dışında kalan Albaraka Türk, Kuveyt Türk, Türkiye Finans Katılım, Vakıf Katılım ve Ziraat Katıım Bankası'nın CAMELS sisteminin kapsadığı 2018 yılı finansal oranlarıdır.

Çalışmanın değişkenlerini oluşturan CAMELS finansal oranlarının seçiminde literatür kısmında ifade edilen çalışmalarda kullanılan ortak oranların olmasına dikkat edilmiştir. Bunun yanı sıra TKBB tarafından sermaye yeterliliği, aktif kalitesi, kazanç, likidite ve gelir-gider gruplarında ele alınan oranlarda göz önünde bulundurulmuştur. Nihai olarak, CAMELS sistemi altı bileşeninin her birinde üçer adet olmak üzere toplam on sekiz finansal oran çalışmanın değişkenlerini oluşturmuştur. CAMELS'e göre katılım bankalarının incelenen finansal oranları aşağıdaki Tablo 2'de sunulmuştur. 
Tablo 2: CAMELS Bileşenleri ve Finansal Oranları

\begin{tabular}{|c|c|}
\hline CAMELS Bileşenleri & Finansal Oranlar \\
\hline \multirow{3}{*}{ SERMAYE YETERLiLIĞi (C) } & Öz Kaynaklar/(Kredi + Piyasa + Operasyonel Riske Esas Tutar) \\
\hline & Öz Kaynaklar/Aktifler \\
\hline & (Öz Kaynaklar-Duran Aktifler)/Aktifler \\
\hline \multirow{3}{*}{ AKTIF KALITESI (A) } & Takipteki Krediler (brüt)/Toplam Krediler ve Alacaklar \\
\hline & Toplam Krediler ve Alacaklar/Aktifler \\
\hline & Özel Karşılıklar/Takipteki Krediler \\
\hline \multirow{3}{*}{ YÖNETIM KALITESI (M) } & Personel Giderleri/Diğer Faaliyet Giderleri \\
\hline & Özel Karşılıklar Sonrası Net Kar Payı/Toplam Faaliyet Giderleri \\
\hline & Kar Payı Dışı Gelirler (net)/Aktifler \\
\hline \multirow{3}{*}{ KAZANÇ (E) } & Sürdürülen Faaliyetler Vergi Öncesi Kar (Zarar)/Aktifler \\
\hline & Net Dönem Karı (Zararı)/Aktifler \\
\hline & Net Dönem Karı (Zararı)/Öz Kaynaklar \\
\hline \multirow{3}{*}{ LiKIDITE (L) } & Likit Aktifler/Aktifler \\
\hline & Likit Aktifler/Kısa Vadeli Yükümlülükler \\
\hline & Türk Parası Likit Aktifler/Aktifler \\
\hline \multirow{3}{*}{$\begin{array}{l}\text { PIYASA RISKINE } \\
\text { DUYARLILIK (S) }\end{array}$} & Yabancı Para Aktifler/YP Pasifler \\
\hline & Net Bilanço Pozisyonu/Öz Kaynaklar \\
\hline & Toplam Toplanan Fonlar/Aktifler \\
\hline
\end{tabular}

Çalışmada yukarıdaki Tablo 2'de yer alan CAMELS'in altı bileşeni için toplam on sekiz finansal oran kullanılmıştır. CAMELS bileşenleri BAHS yönteminin ana kriterleri, finansal oranları ise kriterleri oluşturmuştur. CAMELS kapsamında dikkate alınan altı ana kriter ve on sekiz kriter hakkında on üç kişiden oluşan uzman grubun görüşene başvurulmuştur. Bu uzman grupta üç akademisyen, üç finansal analist, üç denetim ve gözetim kurulu uzmanı ve dört katılım bankası uzmanı vardır. Alınan uzman bilgilerine BAHS yöntemi aşamaları uygulanmış, CAMELS ana kriter ve kriterlerinin ağırlıkları hesaplanmıştır. Sonrasında, ağılıklı CAMELS finansal oranlarına yani kriterlere TOPSIS (Technique for Order Preference by Similarity to Ideal Solution-iddeal Çözümle Benzerlik Yoluyla Sıralama Tekniği) adımları uygulanmak suretiyle, Albaraka Türk, Kuveyt Türk, Türkiye Finans Katılım, Vakıf Katılım ve Ziraat Katılım Bankası'nın finansal performansları hesaplanmış ve bankaların finansal performansları sıralanmıştır. CAMELS finansal oranlarının katılım bankaları faaliyet sonuçlarına etkisi açısından TOPSIS'de yönetim kalitesi bileşeni altındaki Takipteki Krediler (brüt)/Toplam Krediler ve Alacaklar oranı maliyet kriteri, diğer on yedi finansal oranlar ise fayda kriteri olarak analize tabi tutulmuştur.

Şekil 2'de araştırmanın uygulama aşamaları verilmiştir. Uygulama bir birini takip eden üç aşamada tamamlanmıştır. İlk aşamada literatür taramasından elde edilen bilgiler çerçevesinde katılım bankalarının CAMELS finansal oranları belirlenmiştir. İkinci aşamada, CAMELS oranlarının ağılıkları BAHS yöntemiyle hesaplanmıştır. Son aşamada ise, TOPSIS ile katılım bankalarının performansları hesaplanmış ve performans sıralamamaları yapılmıştır. CAMELS sistemine göre bulanık karar verme yaklaşımıyla Türkiye'deki katılım bankalarının performansları değerlendirilmiştir. 
Şekil 2: Uygulama Aşamaları

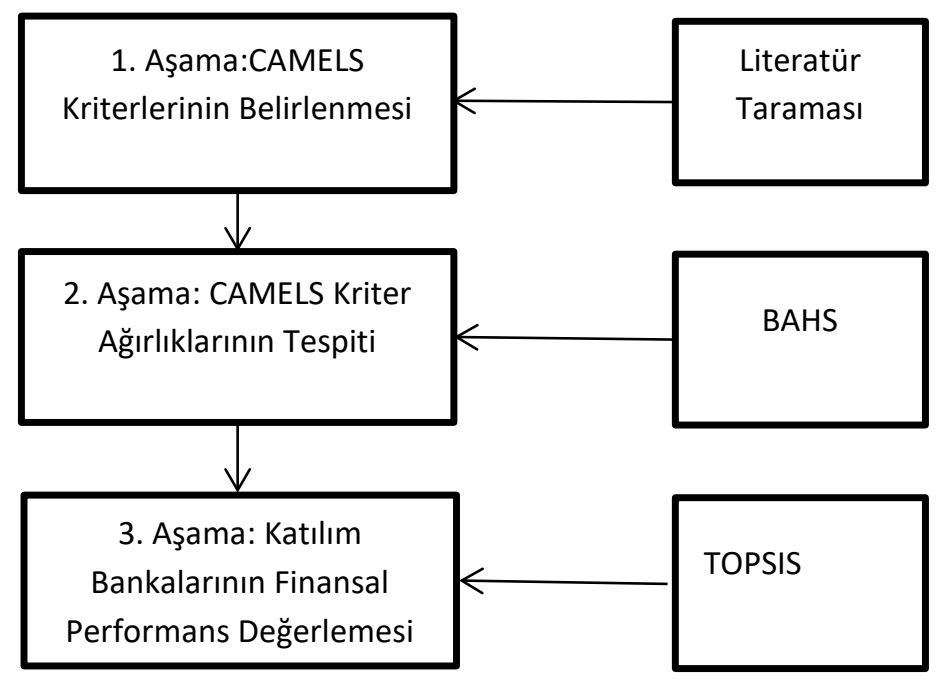

\section{Araştırma Bulguları}

Çalışma bulguları iki başılı halinde sunulmuştur. Illk başlıkta, BAHS yöntemine göre CAMELS finansal oranlarının ağırlıkları belirlenmiştir. İkinci başlıkta ise, TOPSIS ile CAMELS oranlarına göre hesaplanan katılım bankalarının finansal performansı hesaplanmış ve sıralanmıştır.

\subsection{CAMELS Kriter Ağırlıkları}

CAMELS sistemi ana kriter ve kriterlerinin önem düzeylerinin (ağırlıklarının) sayısal olarak ifade edilmesindeki güçlüklerin üstesinden gelinmesinde dilsel ifadelerden yararlanılmıştır. Böylece CAMELS sistemi ana kriterinin ve kriterlerinin ikili karşılaştırmalar yoluyla önem düzeyleri dilsel ifadelerle tanımlanmış ve uzmanlara değerlendirmeleri amacıyla anket formu üzerinde sunulmuştur. Sunulan dilsel ifadeler, dilsel ifadelerin karşılık geldiği üçsen bulanık sayılar ve üçgen bulanık sayı ölçekleri aşağıdaki Tablo 3'te gösterilmiştir.

Tablo 3: Üçgen Bulanık Sayılar ve İkili Karşılaştırma Ölçeği

\begin{tabular}{|c|c|c|}
\hline Önem Düzeyleri & Bulanık Sayılar & Ölçekler \\
\hline Tamamıyla Eşit & & $\left(\begin{array}{lll}1 & 1 & 1\end{array}\right)$ \\
\hline Eşit & $\tilde{1}$ & $\left(\begin{array}{lll}1 & 1 & 3\end{array}\right)$ \\
\hline Orta & $\tilde{3}$ & (1 35$)$ \\
\hline Güçlü & $\tilde{5}$ & (3 57 ) \\
\hline Çok Güçlü & $\tilde{7}$ & (5 79 ) \\
\hline Tamamıyla Güçlü & $\tilde{9}$ & (799) \\
\hline
\end{tabular}

Kaynak: Perçin ve Karakaya (2012): 247.

Çalışmada BAHS yönteminde uygulanmak üzere on üç uzmandan CAMELS finansal oranları hakkındaki yargıları anket yoluyla elde edilmiştir. Bilgisine başvurulan uzman grubun üçü akademisyen, üçü kıdemli finansal analist, üçü denetleme ve düzenleme kurumu uzmanı ve dördü katılım bankası yöneticisidir. Elde edilen uzmanın yargılarının ana kriterlerin birleştirilmiş ikili karşılaştırma matrisi Tablo 4'te tek bir bulanık karar matrisinde verilmiştir. Birleştirme ve üçgen bulanık sayılara dönüştürme işleminin ardından BAHS ile CAMELS ana kriterleri ve ana kriterlerin altında yer alan kriterlerin bulanık sayılara dönüştürülmüş ikili karşılaştırma matrisleri kullanılarak ilgili CAMELS finansal oranlarının önem ağırlıkları hesaplanmıştır. BAHS yönteminin çözüm adımları uygulanmış ve sonuçlar aşağıdaki Tablo 4'te sunulmuştur. 
Tablo 4: Ana Kriterlerin Bulanık ikili Karşılaştırma Matrisi

\begin{tabular}{lcccccc}
\hline & $\mathbf{C}$ & $\mathbf{A}$ & $\mathbf{M}$ & $\mathbf{E}$ & $\mathbf{L}$ & S \\
\hline C & $(111)$ & $(0,194,427,00)$ & $(0,414,939,00)$ & $(0,182,617,00)$ & $(0,544,287,00)$ & $(0,745,299,00)$ \\
A & $(0,211,807,00)$ & $(111)$ & $(0,613,497,00)$ & $(0,312,979,00)$ & $(0,444,917,00)$ & $(0,714,339,00)$ \\
M & $(0,132,917,00)$ & $(0,212,889,00)$ & $(111)$ & $(0,242,787,00)$ & $(0,341,435,00)$ & $(0,543,335,00)$ \\
E & $(0,153,097,00)$ & $(0,113,697,00)$ & $(0,105,139,00)$ & $(111)$ & $(0,123,087,00)$ & $(0,242,847,00)$ \\
L & $(0,112,557,00)$ & $(0,233,207,00)$ & $(0,344,377,00)$ & $(0,242,617,00)$ & $(111)$ & $(0,934,929,00)$ \\
S & $(0,122,217,00)$ & $(0,142,427,00)$ & $(0,363,177,00)$ & $(0,241,155,00)$ & $(0,542,255,00)$ & $(111)$ \\
\hline
\end{tabular}

Tablo 5'deki ana kriterler (CAMELS bileşenleri) incelendiğinde, önem düzeyinin sırasıyla Kazanç $(E)$, Sermaye Yeterliliği (C), Aktif Kalitesi (A), Likidite (L), Yönetim Kalitesi (M) ve Piyasa Riskine Duyarlık (S) biçiminde olduğu görülmüştür. İlk üç sıradaki Kazanç (E), Sermaye Yeterliliği (C) ve Aktif Kalitesi (A) boyutlarının birbirine yakın olacak biçimde \%19-20 ağırlığa sahip olduğu tespit edilmiştir. Bunları Likidite (L) \%16 ile takip etmiştir. Diğer iki boyut olan Yönetim Kalitesi (M) ve Piyasa Riskine Duyarlık (S) ise düşük denebilecek \%12-13 ağırlığındadır. Buradan, uzmanlar nazarında, Türkiye'deki katılım bankaları için CAMELS sisteminin Kazanç (E), Sermaye Yeterliliği (C) ve Aktif Kalitesi (A) boyutlarının yüksek, Likidite (L)'nin orta ve Yönetim Kalitesi (M) ile Piyasa Riskine Duyarlıık (S) ise düşük önemde değerlendirildiği söylenebilir. Dolayısıyla, Türkiye'deki katılım bankaları açısından CAMELS boyutlarından Kazanç (E), Sermaye Yeterliliği (C) ve Aktif Kalitesi (A) boyutlarının daha öne çıktığı bulgusuna varılmıştır.

Tablo 5: CAMELS Oranlarının Ağırlıkları

\begin{tabular}{|c|c|c|c|c|}
\hline CAMELS Bileşenleri & $\%$ & Finansal Oranlar & $\%$ & $\begin{array}{l}\text { Nihai } \\
\%\end{array}$ \\
\hline & & Risk Ayarlı Öz Kaynaklar Oranı & 40 & 28,03 \\
\hline \multirow[t]{3}{*}{ SERMAYE (C) } & 19,97 & Öz Kaynaklar/Aktifler & 35 & 06,99 \\
\hline & & (Öz Kaynaklar-Duran Aktifler)/Aktifler & 24 & 84,95 \\
\hline & & Takipteki Krediler (brüt)/Krediler ve Alacaklar & 40 & 17,63 \\
\hline \multirow[t]{3}{*}{ AKTIF KALITESI (A) } & 19,02 & Toplam Krediler ve Alacaklar/Aktifler & 20, & 75.65 \\
\hline & & Özel Karşılıklar/Takipteki Krediler & 30 & 25,74 \\
\hline & & 113,01 Personel Giderleri/Diğer Faaliyet Giderleri & 33 & 24,32 \\
\hline \multirow[t]{3}{*}{ YÖNETIM KALITESI (M) } & & Özel Karşılıklar Sonrası Net Kar Payı/Faaliyet Gid. & 31, & 54,10 \\
\hline & & Kar Payı Dışı Gelirler (net)/Aktifler & 35 & 34.59 \\
\hline & & Sürdürülen Faaliyetler V.Ö. Kar (Zarar)/Aktifler & 27 & 75,57 \\
\hline \multirow[t]{3}{*}{ KAZANÇ (E) } & 20,01 & Net Dönem Karı (Zararı)/Aktifler & 30 & 86,19 \\
\hline & & Net Dönem Karı (Zararı)/Öz Kaynaklar & 41 & 58,34 \\
\hline & & Likit Aktifler/Aktifler & 37 & 15,94 \\
\hline \multirow[t]{3}{*}{ LIKIDITE (L) } & 16,02 & Likit Aktifler/Kısa Vadeli Yükümlülükler & 37 & 86,06 \\
\hline & & Türk Parası Likit Aktifler/Aktifler & 25 & 14,02 \\
\hline & & Yabancı Para Aktifler/YP Pasifler & 39 & 14,68 \\
\hline \multirow[t]{2}{*}{ DUYARLILIK (S) } & 11,97 & Net Bilanço Pozisyonu/Öz Kaynaklar & 33 & 23,97 \\
\hline & & Toplam Toplanan Fonlar/Aktifler & 27 & 73,32 \\
\hline
\end{tabular}

Tablo 5'de sunulan ana kriterler (CAMELS bileşenleri) altında yer alan kriterlerin (finansal oranların) ağırlıklarına bakıldığında; en yüksek finansal oran \% 8,34 ile Kazanç (E) boyutundaki Öz Kaynak Karlılık Oranı'dır. İkinci sıradaki finansal oran \% 8,03 ile Sermaye Yeterliliği (C) boyutuna ait olan Öz Kaynaklar/(Kredi + Piyasa + Operasyonel Riske Esas Tutar) oranı olan Riske Ayarlı Öz Kaynak Oranı'dır. Üçüncü sıradaki finansal oran, \%7,63 ile Aktif Kalitesi (A) boyutunun Takipteki Krediler Oranı'dır. Dördüncü sıradaki finansal oran, \%6,99 ile Sermaye Yeterliliği (C) boyutundaki Öz Kaynak Oranı'dır. Beşinci sıradaki finansal oran, \% 6,19 ile Kazanç (E) boyutundaki Aktif Karıııı Oranı'dır. Altıncı önemli finansal oran ise, \% 6,06 ile Likidite (L) boyutu altında yer alan Likit Aktifler/Kısa Vadeli Yükümlülükleri olan Cari Oran'dır. 
Öne çıkan kriterlerin (finansal oranların) ve ana kriterlerin (CAMEL bileşenlerinin) sıralamaları örtüşmektedir. İlaveten en önemli altı kriter içerisinde ana kriterlerden Yönetim Kalitesi (M) ve Piyasa Riskine Duyarlık (S) finansal oranlarının yer almadığı görülmektedir. Önemli kriterler içerisinde diğer dört an kritere (CAMELS bileşenine) ait finansal oranların yer aldığı tespit edilmiştir. Bu bulgudan hareketle, Türkiye'deki katılım bankalarında Yönetim Kalitesi (M) ve Piyasa Riskine Duyarlık (S) boyutlarının Kazanç (E), Sermaye Yeterliliği (C), Aktif Kalitesi (A) ve Likidite (L) boyutlarına kıyasla daha az dikkate alındığı söylenebilir.

\subsection{Katılım Bankalarının Finansal Performans Değerlemesi}

Türkiye'de faaliyette bulunan beş katılım bankasının 2018 yılı CAMELS sistemi finansal oranları aşağıdaki Tablo 6'da sunulmuştur.

Tablo 6: Katılım Bankaları CAMELS Oranları (\%)

\begin{tabular}{|c|c|c|c|c|c|}
\hline Finansal Oranlar & $\begin{array}{l}\text { Albaraka } \\
\text { Türk }\end{array}$ & $\begin{array}{l}\text { Kuveyt } \\
\text { Türk }\end{array}$ & $\begin{array}{l}\text { Türkiye } \\
\text { Finans }\end{array}$ & $\begin{array}{l}\text { Vakıf } \\
\text { Katılım }\end{array}$ & $\begin{array}{l}\text { Ziraat } \\
\text { Katılım }\end{array}$ \\
\hline \multicolumn{6}{|l|}{ SERMAYE (C) } \\
\hline Risk Ayarlı Öz Kaynaklar Oranı & 14,21 & 20,02 & 18,58 & 13,60 & 13,53 \\
\hline Öz Kaynaklar/Aktifler & 7,73 & 7,32 & 9,19 & 7,29 & 10,01 \\
\hline $\begin{array}{l}\text { (Öz Kaynaklar-Duran Aktifler)/Aktifler } \\
\text { AKTiF KALiTESi (A) }\end{array}$ & 4,73 & 6,32 & 6,20 & 6,29 & 9,76 \\
\hline Takipteki Krediler (brüt)/Krediler ve Alacak. & 7,21 & 2,57 & 5,81 & 1,82 & 1,35 \\
\hline Toplam Krediler ve Alacaklar/Aktifler & 62,02 & 61,79 & 63,39 & 64,36 & 79,95 \\
\hline $\begin{array}{l}\text { Özel Karşılıklar/Takipteki Krediler } \\
\text { YÖNETiM KALITESi (M) }\end{array}$ & 66,79 & 141,38 & 90,02 & 96,00 & 86,67 \\
\hline Personel Giderleri/Diğer Faaliyet Gid. & 0,32 & 1,17 & 0,95 & 1,98 & 1,45 \\
\hline Özel Karşılık. Son. Net Kar Payı/Faaliyet Gid. & 0,32 & 1,17 & 0,95 & 1,55 & 1,45 \\
\hline Kar Payı Dışı Gelirler (net)/Aktifler & 4,11 & 15,99 & 10,29 & 21,31 & 14,54 \\
\hline \multicolumn{6}{|l|}{ KAZANÇ (E) } \\
\hline Sürdürülen Faaliyetler V.Ö. Kar /Aktifler & 0,32 & 1,17 & 0,95 & 1,98 & 1,45 \\
\hline Net Dönem Karı /Aktifler & 0,32 & 1,17 & 0,95 & 1,55 & 1,45 \\
\hline \multicolumn{5}{|l|}{ LіKIDiTE (L) } & 14,54 \\
\hline Likit Aktifler/Aktifler & 29,02 & 23,23 & 21,33 & 26,39 & 12,60 \\
\hline Likit Aktifler/Kısa Vadeli Yükümlülükler & 44,44 & 39,64 & 34,58 & 40,87 & 23,90 \\
\hline Türk Parası Likit Aktifler/Aktifler & 5,79 & 2,01 & 0,93 & 4,50 & 1,53 \\
\hline \multicolumn{6}{|l|}{ DUYARLILIK (S) } \\
\hline Yabancı Para Aktifler/YP Pasifler & 48,59 & 49,47 & 42,31 & 46,38 & 34,95 \\
\hline Net Bilanço Pozisyonu/Öz Kaynaklar & 0,39 & 0,12 & $-0,15$ & 0,81 & 0,01 \\
\hline Toplam Toplanan Fonlar/Aktifler & 67,79 & 72,73 & 57,09 & 72,45 & 68,28 \\
\hline
\end{tabular}

Tablo \%'de sunulan BAHS ile hesaplanan kriterlerin (finansal oranların) nihai ağılıkları ile Tablo 6'daki katılım bankalarının 2018 yılı CAMELS finansal oranlarına TOPSIS hesaplama aşamaları uygulanmak suretiyle katılım bankalarının finansal performansları ortaya konmuştur. Türkiye'deki katılım bankalarının CAMELS finansal oranlarına göre TOPSIS'le tek bir değerle ifade edilen finansal performansları aşağıdaki Tablo 7'de verilmiştir. 
Tablo 7: Katılım Bankalarının CAMELS Performans Sıralaması

\begin{tabular}{lllcc}
\hline Katılım Bankaları & $\mathrm{Si}^{+}$ & $\mathrm{S}^{-}$ & Yakınlık Katsayısı & Sıralama \\
\hline Albaraka Türk & 0.117 & 0.046 & 0.282 & 5 \\
Kuveyt Türk & 0.090 & 0.066 & 0.422 & 1 \\
Türkiye Finans Katılım & 0.087 & 0.045 & 0.342 & 3 \\
Vakıf Katılım & 0.201 & 0.099 & 0.331 & 4 \\
Ziraat Katılım & 0.106 & 0.067 & 0.386 & 2 \\
\hline
\end{tabular}

Tablo 7'de sunulan TOPSIS bulgularından, Türkiye'deki katılım bankalarının tek boyuta indirgenmiş finansal performans endeksi ve sıralamaları verilmiştir. Performans endeks değerinin yüksekten aşağı doğru düşmesi performansında yüksekten aşağı doğru düştüğünü göstermektedir. Yüksek endeks değeri yüksek performansı düşük endeks değeri ise düşük performansı temsil etmektedir. Dolayısıyla en yüksek performansa sahip katılım bankası Kuveyt Türk iken, en düşük performansa sahip katılım bankası ise, Albaraka Türk olarak hesaplanmıştır. Analiz sonucunda, Türkiye'de katılım bankalarının performans sırlamaları Kuveyt Türk, Ziraat Katılım, Türkiye Finans Katılım, Vakıf Katılım ve Albaraka Türk biçiminde olduğu ortaya konmuştur.

\section{Sonuç ve Değerlendirme}

Türkiye'deki katılım bankacılığının son on yıllık dönemde aktif, kredi, öz kaynak, şube sayısı ve istihdam edilen personel açılarından finans sistemi içerisindeki ağırlı̆̆ında anlamlı artışlar gözlenmiştir. Böylece, Türk finans sistemi içindeki öneminden dolayı katılım bankalarının CAMELS finansal oranları çerçevesinde performansının ele alınması bu çalışmanın konusunu teşkil etmiştir. Çalışmada, performans ölçümü bulanık karar verme yaklaşımıyla gerçekleştirilmiştir. Analizlerde BAHS ve TOPSIS kullanılmıştır. Analizler sonucunda elde edilen bulgular aşağıda özetlenmiştir:

On üç uzmandan elde edilen bilgilerin BAHS ile analizi sonucunda; CAMELS bileşenlerinin önem düzeyi sırasıyla Kazanç (E), Sermaye Yeterliliği (C), Aktif Kalitesi (A), Likidite (L), Yönetim Kalitesi (M) ve Piyasa Riskine Duyarlılık (S) biçiminde olduğu bulunmuştur. CAMELS bileşenlerinde yer alan finansal oranlardan en önemli altısı sırasıyla, Öz Kaynak Karlılığı, Riske Ayarlı Öz Kaynak Oranı, Takipteki Krediler Oranı, Öz Kaynak Oranı, Aktif Karlılık Oranı ve Cari Orandır. Finansal oranlarla ilgili bu bulgu, CAMELS bileşenleri için elde edilen bulguyla uyumludur. Öne çıkan finansal oranlar CAMELS bileşenlerinin sıralamasında elde edilen bileşenleri önem sıralaması olan Kazanç (E), Sermaye Yeterliliği (C), Aktif Kalitesi (A) ve Likidite (L) sıralaması ile örtüşmektedir. Böylece Türkiye'deki katılım bankalarında Yönetim Kalitesi (M) ve Piyasa Riskine Duyarlılık (S) bileşenlerinin Kazanç (E), Sermaye Yeterliliği (C), Aktif Kalitesi (A) ve Likidite (L) bileşenlerine kıyasla daha az dikkate alındığı söylenebilir.

TOPSIS analiziyle Türkiye'deki katılım bankalarının finansal performans endeksine göre sıralaması sırasıyla Kuveyt Türk, Ziraat Katılım, Türkiye Finans Katılım, Vakıf Katılım ve Albaraka Türk olarak tespit edilmiştir. Elde edilen sırlama ile katılım bankalarının 2018 yılı aktif büyüklükleri ve net karındaki artışlar birbirine yakındır. Dolayısıyla, Türkiye'deki katılım bankaları için aktif büyüklüğü yani ölçek ekonomisi ile kazanç artırma kabiliyeti yani faaliyetler sonucu fon yaratma kabiliyetinin performansın önemli göstergeleri olduğu söylenebilir.

Gelecek çalışmalarda, katılım bankalarının performanslarının ölçümünde farklı yöntem ve farklı karar verme kriterleriyle alternatif uygulamalar yapılabilir. Bu amaç doğrultusunda, BAHS'ye alternatif olarak bulanık veya bütünleşik ASS, TOPSIS veya VIKOR, ELECTRE, PROMETHEE gibi diğer ÇKKV yöntemleri ile katılım bankalarının performans ölçümlerinin yapılması önerilebilir. Performans kriterleri olarak finansal oranların yanında finansal olmayan bilgilerin birlikte kullanımı yoluyla daha geniş değerlendirmeler yapılabilir. İlaveten, banka yönetimleri, politika belirleyiciler ve düzenleyiciler ÇKKV yöntemlerini kullanarak ihtiyaca daha iyi cevap verebilecek performans ölçüm ve değerlendirme sistemi geliştirebilirler. 


\section{Kaynakça}

Abdullayev, M. (2013). Türk Bankacılık Sektöründe Dezenflasyon Sürecinde CAMELS Analizi. Dumlupınar Üniversitesi Sosyal Bilimler Dergisi, (37), 97-112.

Anderson, D., Sweeney, D. ve Williams, T. (1997). An Inroduction To Management Science, Prentice Hall.

Avkiran, N.K., ve Cai, L. 2012. Predicting Bank Financial Distress Prior to Crises, New Zealand Finance Colloquium.

Altemur, N., Karaca, S. S. ve Güvemli, B. (2018). Türkiye'deki Yabancı Sermayeli Bankaların CAMELS Analizi ile Performanslarının Ölçülmesi. Journal of International Management, Educational and Economics Perspective, 6 (1), 57-65.

Aytekin, S. ve Sakarya, Ş. (2013). BIST'deki Mevduat Bankalarının Finansal Performanslarının 2001 ve 2008 Finansal Krizleri Çerçevesinde CAMELS Derecelendirme Sistemi ile Değerlendirilmesi. Abant izzet Baysal Üniversitesi Sosyal Bilimler Enstitüsü Dergisi, 13(2): 25-58.

Bao, S.S. (201). Credit Analysis of Commercial Banks Based on CAMEL Model-Taking Agricultural Bank of China as An Example. Mall Mod., 4, 114-115.

Barr, R.S., Seiford, L.M. ve Siems, T.F. (1994). Forecasting Bank Failure: A Non-Parametric Frontier Estimation Approach. Reherches Économiques de Louvain/Louvain Econ, Rev., 60, 417429.

Bayramoğlu, M. F. ve Gürsoy, i. (2017). Türkiye'de Faaliyet Gösteren Mevduat Bankalarının Bireysel Ve Sektörel Risk Derecelendirmesi: Bir CAMELS Analizi Uygulaması. Yönetim ve Ekonomi Araştırmaları Dergisi, 15 (1): 1-19.

Benitez, J. M.. Martin, J. C. ve Roman, C. (2007). Using Fuzzy Number for Measuring Quality of Service in the Hotel Industry. Tourism Management, 28(2), 544-555.

Betz, F., Oprica, S., Peltonen, T. A. ve Sarlin, P. (2014). Predicting Distress in European Banks, Journal of Banking and Finance, 45, 225-241.

Bulut, H. İ.. ve Er, B. (2012). Katılım Finansmanı, Türkiye Katılım Bankaları Birliği Yayın No:3. İstanbul.

Büyüközkan, G. ve Ruan, D. (2007). Evaluating Government Websites Based on a Fuzzy Multiple Criteria Decision-Making Approach. International Journal of Uncertainty, Fuzziness and Knowledge-Based Systems, 15(03), 321-343.

Çakır, S. ve Perçin, S. (2013). Çok Kriterli Karar Verme Teknikleriyle Lojistik Firmalarında Performans Ölçümü. Ege Akademik Bakış, 13(4), 449-459.

Canbaş, S.. ve Doğukanlı, H. (2012). Finansal Piyasalar, 5. Baskı, Karahan Kitabevi, Adana.

Chang, D. Y. (1996). Applications of the Extent Analysis Method on Fuzzy AHP. European Journal Of Operational Research, 95(3), 649-655.

Chen, C. T., Lin, C. T. ve Huang, S. F. (2006). A Fuzzy Approach for Supplier Evaluation and Selection in Supply Chain Management. International Journal of Production Economics, 102, 289301.

Cole, R.A., Gunther, J.W., 1995. Separating the Likelihood and Timing of Bank Failure. Journal of Banking and Finance, 19, 1073-1089.

Cole, R. A. ve Gunther, J. W. (1998). Predicting Bank Failures: A Comparison of On- and Off-Site Monitoring Systems, Journal of Financial Services Research, 13 (2), 103-117. 
Cole, R. A. ve Wu, Q. (2009). Predicting Bank Failures Using a Simple Dynamic Hazard Model, In 22nd Australasian Finance and Banking Conference, 1-29.

Christopoulos, A.G., Mylonakis, J., ve Diktapanidis, P. (2011). Could Lehman Brothers' Collapse be Anticipated? An Examination Using CAMELS Rating System. International Business Research, 4(2), 11-19.

Curry, T. J.. Elmer, P. .J. ve Fissel, G. S. (2003). Using Market Information to Help Identify Distressed Institutions: A Regulatory Perspective. FDIC Banking Review, 15(3), 1-16.

Çağıl, G. ve Mukhtarov, S. (2014). Azerbaycan Ticari Bankacılık Sektörünün CAMELS Yöntemi ile Performans Analizi. Marmara Üniversitesi Öneri Dergisi, 11 (41), 77-94.

Çinko, M. ve Avcı, E. (2008). CAMELS Dereceleme Sistemi ve Türk Ticari Bankacılık Sektöründe Başarısızlık Tahmini. BDDK Bankacılık ve Finansal Piyasalar Dergisi, 2 (2),.25-48.

Deyoung, R. (1998). Management Quality and X-Inefficiency in National Banks. Journal Financial Services Research, 13, 5-22.

Dinçer, H., ve Görener, A. (2011). Performans Değerlendirmesinde AHP-VIKOR ve AHP-TOPSIS Yaklaşımları: Hizmet Sektöründe Bir Uygulama. Mühendislik ve Fen Bilimleri Dergisi Sigma, 29, 244-260.

Dincer, H., Yuksel, S. ve Hacioglu, U. (2015). CAMELS-Based determinants for the credit rating of Turkish Deposit Banks. International Journal Finance Banking Studies, 4, 1-17.

Dursun, G. D. ve Bozkır, B. (2018). Türkiye'de Faaliyet Gösteren Ticari Bankaların Aktif Kalitesinin Topsis Yöntemi ile Ölçümü. Ekonomi, Politika \& Finans Araştırmaları Dergisi, 3(3), 243258.

Ecer, F. (2014). A Hybrid Banking Websites Quality Evaluation Model Using AHP And COPRAS-G: A Turkey Case. Technological and Economic Development of Economy, 20(4), 758-782.

Ege, İ., Topaloğlu, E.E. ve Karakozak, Ö. (2015). CAMELS Performans Değerleme Modeli: Türkiye'deki Mevduat Bankaları Üzerine Ampirik Bir Uygulama, Niğde Üniversitesi iktisadi ve Idari Bilimler Fakültesi Dergisi, 8 (4), 109-126.

Eleren, A.. (2007). Markaların Tüketici Tercih Kriterlerine Göre Analitik Hiyerarşi Süreci Yöntemi ile Değerlendirilmesi: Beyaz Eşya Sektöründe Bir Uygulama. Celal Bayar Üniversitesi iiBF Dergisi, 14(2), 47-64.

Erdoğan, S. ve Karaca, S. S. (2018). Türk Bankacılık Sektörünün 2009-2016 Dönemi CAMELS Derecelendirme Sistemi ile Performans Analizi, Journal of International Management, Educational and Economics Perspectives, 6 (3), 23-39.

Ersoy, E. (2003). CAMEL Derecelendirme Sistemi'ne Göre TMSF'ye Devredilen ve Devredilmeyen Bankaların Karşılaştırmalı Analizi, Active, Eylül-Ekim, 1-9.

Ertuğrul, i. ve Karakaşoğlu, N. (2008). Banka Şube Performanslarının VIKOR Yöntemi ile Değerlendirilmesi. Endüstri Mühendisliği Dergisi YA/EM Özel SayısI, 20 (1), 19-28.

Ertuğrul, i. ve Karakaşoğlu, N. (2009). Performance Evaluation of Turkish Cement Firms with Fuzzy Analytic Hierarchy Process and TOPSIS Methods. Expert Systems with Applications, 36, 702-715.

Eyüboğlu, K. (2016). Comparison The Financial Performances of Developing Countries' Banking Sectors with Topsis Method. Sosyal Bilimler Araştırmaları Dergisi, (14), 220-236.

Gilbert, R.A.. Meye, A. P. ve Vaughan, M. D. (2000). The Role of a CAMEL Downgrade Model in Bank Surveillance. Federal Reserve Bank of St. Louis Working Paper. No:2000-021A, 1-34. 
Gümüş, F. B. ve Nalbantoğlu, Ö. (2015). Türk Bankacılık Sektörünün CAMELS Analizi Yöntemiyle 2002-2013 Yılları Arasında Performans Analizi, Afyon Kocatepe Üniversitesi iiBF Dergisi, 17(2), 83-106.

Güney, S. ve Ilgın, K. S. (2015). Türk Mevduat Bankalarında CAMELS Modelinin İncelenmesi ve Örnek Bir Uygulama, Dokuz Eylül Üniversitesi Sosyal Bilimler Enstitüsü Dergisi, 17 (3), 303331.

Gündoğdu, A. (2017). Türkiye'de Mevduat Bankalarının CAMELS Analizi. Bankacılık ve Finansal Araştırmalar Dergisi, 4(2), 26-43.

Gündoğdu, A. (2018). Türkiye'de Katılım Bankalarının Finansal Performansının Gri illişki Analizi ile Ölçülmesi. Uluslararası Iktisadi ve Idari Incelemeler Dergisi, 17. UíK Özel Sayısı, 201-214.

Günsel, N. (2007). Financial Ratios and the Probabilistic Prediction of Bank Failure in North Cyprus, European Journal of Scientific Research, 18 (2), 191-200.

Helhel, Y. ve Varshalomidze, M. (2014). Gürcistan'da Faaliyet Gösteren Yerli Sermayeli Özel Ticari Bankaların CAMELS Derecelendirme Sistemi ile Değerlendirilmesi. 18. Finans Sempozyumu Denizli, 413-424.

Islam, M.T.U. ve Ashrafuzzaman, M., (2016). A Comparative Study of Islamic and Conventional Banking in Bangladesh: Camel Analysis. Journal of Business and Technology (Dhaka), 10 (1), 73-91.

İç, Y.T. ve Yurdakul. M. (2000). Analitik Hiyerarşi Süreci Yöntemini Kullanan Bir Kredi Değerlendirme Sistemi. Gazi Üniversitesi MMF Dergisi, 15 (1), 1-14.

İslamoğlu, M., Apan, M., ve Öztel, A. (2015). An Evaluation of the Financial Performance of REIT's in Borsa Istanbul: A Case Study Using the Entropy-Based TOPSIS Method. International Journal of Financial Research, 6(2), 124-138.

Jaffar, M., ve Manarvi, I. (2011), Performance Comparison of Islamic and Conventional Banks in Pakistan. Global Journal of Management and Business Research, 11 (1), 61-66.

Kahraman, C., Cebeci, U., ve Ruan, D. (2004). Multi-attribute Comparison of Catering Service Companies Using Fuzzy AHP: The Case of Turkey. International Journal of Production Economics, 87(2), 171-184.

Kandemir, T. ve Arıcı, N.D. (2013). Mevduat Bankalarında CAMELS Performans Değerleme Modeli Üzerine Karşılaştırmalı Bir Çalışma (2001-2010). Süleyman Demirel Üniversitesi Iktisadi ve idari Bilimler Fakültesi Dergisi, 18 (1), 61-87.

Karakaya, A. (2017), Türkiye'deki Katılım Bankalarının AHS ve TOPSIS Yöntemleri ile Finansal Performansı: CAMELS Oranları, International Congress of Islamic Economy, Finance and Ethics, 29 Nisan 2017, İstanbul, 33-49.

Kaya, T., ve Kahraman, C. (2011). Fuzzy Multiple Criteria Forestry Decision Making Based on an Integrated VIKOR and AHP Approach. Expert Systems with Applications, 38, 7326-7333.

Kaya, Y. T. (2001). Türk Bankacılık Sektöründe CAMELS Analizi. Bankacılık Düzenleme ve Denetleme Kurumu MSPD Çalışma Raporu, 6, 1-20.

Kılıç, Ç. ve Fettahoğlu, A. (2005). Türk Bankacılık Sektörünün CAMELS Analizi ile Değerlendirilmesi. 9. Ulusal Finans Sempozyumu, 89-128.

King, T.B.. D. A. Nuxoll ve T. J. Yeager. (2006). Are the Causes of Bank Distress Changing? Can the Researchers Keep up?. The Federal Reserve Bank of St. Louis Review. 57-80.

Korkmaz, T. ve Ceylan, A. (2012). Sermaye Piyasası ve Menkul Değer Analizi, 6. Baskı, Ekin Basım Yayın Dağıtım, Bursa. 
Kumar, P.R., ve Ravi, V., (2007). Bankruptcy Prediction in Banks and Firms via Statistical and Intelligent Techniques: A Review. . European Journal of Operational Research, 180, 1-28.

Männasoo, K., ve Mayes, D.G., (2009). Explaining bank distress in Eastern European transition economies. Journal of Banking and Finance, 33, 244-253.

Merchant, I.P., (2012). Empirical Study of Islamic Banks Versus Conventional Banks of GCC. Global Journal of Management and Business Research,12 (20), 20-37.

Muhmad, S.N. ve Hashim, H.A. (2015). Using The CAMEL Framework in Assessing Bank Performance in Malaysia. International Journal of Economics, Management and Accounting, 23 (1), 109-127.

Nurazi, R. ve Evans, M. (2005). An Indonesian Study of the Use of CAMEL(S) Ratios as Predictors of Bank Failure. Journal of Economic and Social Policy, 10 (1), 1-23.

Özyörük, B. ve Özcan, E. C. (2008). Analitik Hiyerarşi Sürecinin Tedarikçi Seçiminde Uygulanması: Otomotiv Sektöründen Bir Örnek. Süleyman Demirel Üniversitesi iiBF Dergisi, 13 (1), 133144.

Parlakkaya, R. ve Akten Çürük, A. (2011). Finansal Rasyoların Katılım Bankaları ve Geleneksel Bankalar Arasında Bir Tasnif Aracı Olarak Kullanımı: Türkiye Örneği. Ege Akademik Bakış, 11 (3), 397-405.

Perçin, S. (2009). Evaluation of Third-Party Logistics (3PL) Providers by Using a Two Phase AHP and TOPSIS Methodology. Benchmarking: An International Journal, 16(5), 588-604.

Perçin, S. ve Karakaya, A. (2012). Bulanık Karar Verme Yöntemleriyle Türkiye'de Bilişim Teknolojisi Firmalarının Finansal Performanslarının Değerlendirilmesi. Marmara Üniversitesi iiBF Dergisi, 33(2), 241-266.

Poghosyan, T., ve C`ihák, M., 2009. Distress in European Banks: An Analysis Based on A New Dataset. IMF Working Papers, 1-37.

Ramirez, C.D., Curry, T.J. ve Fissel, G.S. (2005). Does Bank Supervision Have Side Effects? Evidence from CAMEL Ratings. FDIC, 1-25.

Roman, A. ve Şargu, A. C. (2013). Analysing the Financial Soundness of the Commercial Banks in Romania: An Approach Based on the CAMELS Framework. Procedia Economics and Finance, 6, 703-712.

Rozzani, N. ve Rahman, R.A. (2013). CAMELS and Performance Evaluation of Banks in Malaysia: Conventional Versus Islamic. Journal of Islamic Finance and Business Research, 2 (1), 3645.

Saaty, T. (1987). Concepts. Theory and Techniques. Rank Generation. Preservation and Reversal in the Analytic Hierarchy Decision Process. Decision Sciences, 18, 157-177.

Saaty, T. (1990). How To Make A Decision: The Analytic Hierarchy Process. European Journal of Operational Research, 48, 9-26.

Saaty, T. (2001). Decision Making for Leaders. RWS Publication.

Saaty, T.. (2006). Fundamentals of Decision Making and Priority Theory With The Analytic Hierarchy Process, 3. Baskı, Pittsburg.

Sarker, A., (2005). CAMELS Rating System in the Context of Islamic Banking: A Proposed ' $S$ ' for Shariah Framework. Journal of Islamic Economics and Finance, 1 (1), 78-84. 
Shaddady, A. ve Tomoe, M. (2019). Investigation of the Effects of Financial Regulation and Supervision on Bank Stability: The Application of CAMELS-DEA to Quantile Regressions. Journal International Financial Markets, Inst. Money, 58, 96-116.

Solak, S. (2010). Türk Ticari Bankacılık Sektörünün 2001 Krizi Öncesi ve Sonrası Camels Analizi. (Yayınlanmış Yüksek Lisans Tezi), Kütahya: Dumlupınar Üniversitesi Sosyal Bilimler Enstitüsü.

Ustasüleyman. T. ve Çelik, P. (2015). AHS ve Bulanık PROMETHEE Yöntemleriyle Destinasyon Seçimini Etkileyen Faktörlerin Önem Derecesinin Belirlenmesi ve En Uygun Destinasyon Seçimi. Uluslararası Iktisadi ve Idari Incelemeler Dergisi 14, 85-102.

Tam, M. C. Y. ve Tummala, V M. R.. (2001). An Application of The AHP in Vendor Selection of a Telecommunications System. Omega, 29 (2), 171-182.

Tao, X.L. (2017). Bank of Beijing's Operational Performance Evaluation Based on Camel Rating System, Taxpaying, 15, 133-149.

TKBB, (2018). Katılım Bankaları 2018.http://www.tkbb.org.tr/Documents/Yayınlar/KATILIM_ 2018_TR_final.pdf (11.06.2019).

Triantaphyllou. E.. B., Shu. S., Nieto S. ve Ray, S. (1998). Multi-Criteria Decision Making: An Operations Research Approach. Encyclopedia of Electrical and Electronics Engineering, (J.G. Webster. Ed.), John Wiley \& Sons, New York, NY. 15, 175-186.

Tsai, H. Y., Huang B. H., ve Wang, A. S. (2008). Combining ANP and TOPSIS Concepts for Evaluation the Performance of Property-Liability Insurance Companies. Journal of Social Sciences, 4(1), 56-61.

Uslu, A. (2019). Türkiye'deki Yabancı Sermayeli Bankaların CAMELS Analizi ile Performanslarının Ölçümü. Muhasebe ve Finansman Dergisi, (82), 199-220.

Varga,. L.G.. (1990). An Overview of the Analytic Hierarchy Process and its Applications. European Journal of Operational Research, 48, 2-8.

Vousinas, G. (2018). Analyzing the Financial Performance of Greek Systemic Banks During Crisis. An Application of Camels Rating System. SSRN Electron. J. 13, 45-54.

Wanke, P., Barros, C.P. ve Faria, J.R., (2015). Financial Distress Drivers in Brazilian Banks: A Dynamic Slacks Approach. European Journal of Operational Research, 240, 258-268.

Wanke, P., Azad, M.A.K. ve Barros, C.P., 2016. Financial Distress and the Malaysian Dual Banking System: A Dynamic Slacks Approach. Journal of Banking and Finance, 66, 1-18.

Wanke, P., Azad, M.A.K., Barros, C.P. ve Hadi-Vencheh, A. 2016. Predicting Performance in ASEAN Banks: An Integrated Fuzzy MCDM-Neural Network Approach. Expert Systems, 33 (3), 213-229.

Whalen, G. ve Thomson, J.B. (1988). Using Financial Data to Identify Changes in Bank Condition. Economic Review-Federal Reserve Bank of Cleveland, 24 (2), 17-26.

Winston W. ve Albrigt, C. (1997). Management Science, Duxbury.

Wu, H. Y., Tzeng, G. H., ve Chen Y. H. (2009). A Fuzzy MCDM Approach for Evaluating Banking Performance Based on Balanced Scorecard. Expert Systems with Applications, 36, 1013510147.

Wu, C. R., Lin, C. T., ve Tsai, P. T. (2010). Evaluating Business Performance of Wealth Management Banks. European Journal of Operational Research, 207, 971-979. 
Yalçın Seçme, N., Bayrakdaroğlu A., ve Kahraman, C. (2009). Fuzzy Performance Evaluation in Turkish Banking Sector Using Analytic Hierarchy Process and TOPSIS. Expert Systems with Applications, 36, 11699-11709.

Zadeh, L. A. (1965). Fuzzy Sets. Information And Control, 8(3), 338-353.

Zhao, H., Sinha, A. P. ve Ge, W. (2009). Effects of Feature Construction on Classification Performance: An Empirical Study in Bank Failure Prediction. Expert Systems with Applications, 36, 2633-2644. 
FINANCIAL PERFORMANCE OF PARTICIPATION BANKS WITH FUZZY DECISION MAKING APPROACH

\section{Extended Abstract}

Aim: Islamic banks are growing faster than conventional banks. This is due to the principles of interest-free finance. The same is true of participation banks in Turkey. The increasing weight within the financial system makes the performance of participation banks important. This study aims to measure performance of participation banks in Turkey, according to the CAMELS system. To achieve this aim, Fuzzy Multi Criteria Decision Making (MCDM) methods have been used instead of conventional methods.

Method: This study, it is used Fuzzy MCDM methodology that contains Fuzzy Analytic Hierarchy Process (AHP), and TOPSIS. Study data set covers financial ratios of Albaraka Turkish, Kuwait Turkish, Turkey Finans Participation, Vakif Participation, and Ziraat Participation Bank. Financial ratios are the annual data for 2018. First, the weights of the financial ratios that make up the CAMELS components are calculated by BAHS (Fuzzy Analytic Hierarchy Process). Then, TOPSIS and participation banks were ranked in terms of financial performance. CAMELS is consists of six components the capital (C), asset quality (A), management quality (M), earnings (E), liquidity (L), and market risk sensitive (S). In this study, a total of 18 financial ratios were used within the framework of CAMELS. These six components of the CAMELS system are the main criteria. The criteria consist of three financial ratios, each of which is contained within each of these components. Surveys were applied to financial analysts and managers of participation banks in order to determine the main criteria and the weights of the criteria. Then, weights were calculated by Fuzzy AHP method according to the information obtained from experts.

Findings: The six components of CAMELS are the main criteria in BAHS analysis. Eighteen financial ratios are the criteria in BAHS analysis. In the BAHS analysis, the order of the main criteria according to their weights was found as earnings, capital, asset quality, liquidity, management quality and sensitivity. The highest weighted criteria are equity profitability ratio, risk adjusted equity ratio, non-performing loans ratio, equity ratio, asset profitability ratio and current ratio. As a result of analysis of the financial performance of participation banks TOPSIS, Kuwait Turkish, Ziraat Participation, Vakif Participation, Turkey Finans Participation, and Albaraka Turkish found.

Conclusion: The performance ranking of the participation banks was realized with the fuzzy decision making method used for general performance ranking. This model proposed in the study can be used by bank managers and supervisors as an effective performance evaluation method. It is thought that model managers and supervisors will facilitate effective decision making. In addition, the proposed fuzzy decision making model can be applied to different areas. 
